\title{
UPAYA MENINGKATKAN KEBERANIAN SISWA BERTANYA DAN PRESTASI BELAJAR DENGAN PEMBELAJARAN THINK PAIR SHARE (TPS) BERBANTUAN MEDIA
}

\author{
Mustakim \\ Solikhin \\ Guru SMP Negeri 2 Patean \\ e-mail: mustakim200671@gmail.com
}

\begin{abstract}
Class Action Research was motivated by a lack of courage and ask the students of class VII student achievement SMP 2 Patean Kendal especially Class VII-A. To overcome this problem researchers use a learning Think Pair Share (TPS) aided media quiz game Who's He (KSD). Formulation of the problem in this study were (1) Is the TPS-assisted learning media KSD game on triangular and quadrilateral material can increase the courage to ask students and student achievement class VII-A SMP Negeri 2 Patean Semester II Academic Year 2014/2015 ?; (2) Is the TPS-assisted learning media KSD game on triangular and quadrilateral material for students of classes VII-A SMP Negeri 2 Patean Semester II Academic Year 2014/2015 can achieve mastery programmed? To address the above problems, it is done classroom action research conducted in two (2) cycles, each consisting of planning, implementation, observation, and reflection. Data collected through observation, interview and test. The subjects were students of class VIIA SMP Negeri 2 Patean Kendal totaling 27 students with a composition of 16 boys and 11 female student. The study was conducted in January to June 2015. The indicators in this study were (1) More than $75 \%$ of students courage students to ask bold minimal category; (2) The average value of student achievement of at least 75; (3) More than 75\% of students reach the minimum learning achievement KKM is 75. The results showed that the students' courage to ask the brave minimal category increased $34 \%$, from the initial conditions as much as $44 \%$ increased to $63 \%$ in the first cycle and $78 \%$ in Cycle II. The average value of student achievement has increased 23 from the average value of learning achievement in the initial conditions 59 to 72 in the first cycle and 82 in the second cycle. Likewise mastery learning has increased $41 \%$, from the initial conditions of $37 \%$ rising to $67 \%$ in the first cycle and $78 \%$ in Cycle II. The conclusion of this Class Action Research is a learning Think Pair Share (TPS) game media aided KSD on triangular and quadrilateral material can increase the courage to ask students and student achievement class VII-A SMP Negeri 2 Patean Semester II Academic Year 2014/2015.
\end{abstract}

Keywords: academic achievement, courage students ask, learning Think Pair Share (TPS)

\footnotetext{
ABSTRAK

Penelitian Tindakan Kelas ini dilatarbelakangi oleh rendahnya keberanian siswa bertanya dan prestasi belajar siswa kelas VII SMP Negeri 2 Patean Kendal terutama kelas VII-A. Untuk mengatasinya peneliti menggunakan pembelajaran Think Pair Share (TPS)
} 
berbantuan media permainan Kuis Siapa Dia (KSD). Rumusan masalah dalam penelitian ini adalah (1) Apakah pembelajaran TPS berbantuan media permainan KSD pada materi segitiga dan segiempat dapat meningkatkan keberanian siswa bertanya dan prestasi belajar siswa kelas VII-A SMP Negeri 2 Patean Semester II Tahun Pelajaran 2014/2015?; (2) Apakah pembelajaran TPS berbantuan media permainan KSD pada materi segitiga dan segiempat bagi siswa kelas VII-A SMP Negeri 2 Patean Semester II Tahun Pelajaran 2014/2015 dapat mencapai ketuntasan yang diprogram? Untuk membahas permasalahan di atas, maka dilakukan penelitian tindakan kelas yang dilaksanakan dalam 2 (dua) siklus, masing-masing terdiri dari perencanaan, pelaksanaan, pengamatan, dan refleksi. Pengumpulan data dilakukan melalui kegiatan observasi, wawancara, dan tes. Subjek penelitian adalah siswa kelas VII-A SMP Negeri 2 Patean Kendal yang berjumlah 27 siswa dengan komposisi 16 siswa putra dan 11 siswa putri. Penelitian dilakukan pada bulan Januari sampai dengan Juni 2015. Indikator dalam penelitian ini adalah (1) Lebih dari 75\% siswa keberanian siswa bertanya pada kategori minimal berani; (2) Rata-rata nilai prestasi belajar siswa minimal 75; (3) Lebih dari 75\% siswa prestasi belajar mencapai batas minimal KKM yaitu 75. Hasil penelitian menunjukkan bahwa keberanian siswa bertanya dengan kategori minimal berani mengalami peningkatan $34 \%$, dari kondisi awal sebanyak $44 \%$ meningkat menjadi $63 \%$ pada Siklus I dan $78 \%$ pada Siklus II. Rata-rata nilai prestasi belajar siswa mengalami peningkatan 23 dari rata-rata nilai prestasi belajar pada kondisi awal 59 menjadi 72 pada Siklus I dan 82 pada Siklus II. Demikian juga ketuntasan belajar mengalami peningkatan $41 \%$, dari kondisi awal $37 \%$ meningkat menjadi $67 \%$ pada Siklus I dan $78 \%$ pada Siklus II. Kesimpulan dari Penelitian Tindakan Kelas ini adalah pembelajaran Think Pair Share (TPS) berbantuan media permainan KSD pada materi segitiga dan segiempat dapat meningkatkan keberanian siswa bertanya dan prestasi belajar siswa kelas VII-A SMP Negeri 2 Patean Semester II Tahun Pelajaran 2014/2015.

Kata kunci: keberanian siswa bertanya, pembelajaran think pair share (TPS), prestasi belajar

Pada Permendiknas No 22 Tahun 2006 tentang Standar Isi (mata pelajaran matematika SMP/MTs.) dijelaskan bahwa mata pelajaran matematika diberikan kepada siswa bertujuan agar peserta didik (siswa) memiliki kemampuan antara lain (1) Memahami konsep matematika, menjelaskan keterkaitan antarkonsep dan mengaplikasikan konsep atau algoritma, secara luwes, akurat, efisien, dan tepat, dalam pemecahan masalah; (2) Menggunakan penalaran pada pola dan sifat, melakukan manipulasi matematika dalam membuat generalisasi, menyusun bukti, atau menjelaskan gagasan dan pernyataan matematika; (3) Memecahkan masalah yang meliputi kemampuan memahami masalah, merancang model matematika, menyelesaikan model dan menafsirkan solusi yang diperoleh; (4) Mengomunikasikan gagasan dengan simbol, tabel, diagram, atau media lain untuk memperjelas keadaan atau masalah; dan (5) Memiliki sikap menghargai kegunaan matematika dalam kehidupan, yaitu memiliki rasa ingin tahu, perhatian, dan minat dalam mempelajari matematika, serta sikap ulet dan percaya diri dalam pemecahan masalah. Diharapkan setelah siswa belajar matematika mereka mampu berpikir logis, analitis, sistematis, kritis, dan kreatif, serta kemampuan bekerjasama sehingga mereka memiliki kemampuan memperoleh, mengelola, dan memanfaatkan informasi untuk bertahan hidup pada keadaan yang selalu berubah, tidak pasti, dan kompetitif. 
Pentingnya menguasai matematika ternyata tidak membuat siswa mempelajari matematika dengan aktif, inovatif, kreatif, dan senang. Kebanyakan siswa menganggap belajar matematika adalah aktivitas yang membosankan, tidak menyenangkan, duduk berjam-jam dengan mencurahkan perhatian dan pikiran pada suatu materi pelajaran matematika, baik yang sedang disampaikan guru maupun yang sedang dihadapi di meja belajar. Kegiatan ini hampir selalu dirasakan sebagai beban daripada upaya aktif untuk memperoleh ilmu. Bahkan komentar klasik siswa terhadap mata pelajaran matematika adalah "pelajaran sulit" sehingga berakibat prestasi belajar siswa rendah. Kondisi seperti ini tidak jauh berbeda dengan siswa kelas VII-A SMP Negeri 2 Patean Kendal. Dari pengamatan peneliti selama mengajar di kelas VII-A ada 12 siswa (44\%) yang berani mengajukan pertanyaan kepada guru apabila menjumpai hal-hal yang menurut mereka tidak paham, sedangkan 15 siswa $(56 \%)$ tidak berani bertanya kepada guru dengan alasan takut, malu dikira oleh temannya sebagai siswa yang bodoh sehingga berakibat prestasi belajar mereka juga belum memuaskan. Dari 27 siswa hanya 12 siswa yang tuntas belajar. Kondisi seperti ini terjadi karena guru dalam melakukan pembelajaran di kelas masih menggunakan model dan metode mengajar kurang bervariasi, monoton hanya mengedepankan ceramah dan tugas saja apalagi memberi tugas yang menantang bagi sisa untuk mencoba cara lain atau bahkan menemukan cara sendiri yang tetap logis. Untuk mengatasi masalah di atas, salah satu solusinya adalah guru menerapkan model pembelajaran yang tepat. Karena ketidaktepatan guru dalam merancang dan melaksanakan pembelajaran menjadi salah satu faktor penyebab prestasi belajar matematika siswa rendah. Kesulitan siswa dalam mempelajari matematika di sekolah di samping disebabkan oleh sifat abstrak matematika itu sendiri, juga disinyalir disebabkan oleh guru yang kurang tepat dalam merancang dan melaksanakan pembelajaran matematika di kelas Rochmad (2008).

Dalam penelitian tindakan kelas ini model pembelajaran yang digunakan untuk mengatasi permasalahan di atas adalah model Pembelajaran Kooperatif Think Pair Share (TPS) dengan beberapa keunggulan antara lain adalah (1) memberi siswa kesempatan untuk bekerja sendiri serta bekerja sama dengan orang lain, (2) optimalisasi partisipasi siswa karena dengan metode klasikal yang memungkinkan hanya satu siswa yang maju dan membagikan hasilnya untuk seluruh kelas, Think Pair Share memberi kesempatan sedikitnya delapan kali lebih banyak kepada setiap siswa untuk dikenali dan menunjukkan partisipasi mereka kepada orang lain, (3) Think Pair Share bisa digunakan untuk semua mata pelajaran dan semua tingkatan usia anak didik (Lie, 2010: 57). Dalam penelitian ini media yang digunakan adalah Media Permainan Kuis Siapa Dia (KSD) untuk meningkatkan keberanian siswa bertanya, keberanian siswa dalam mengajukan pertanyaan baik kepada guru maupun kepada teman sehingga dapat meningkatkan pula prestasi belajar siswa.

Berdasarkan uraian latar belakang masalah, peneliti dapat mengidentifikasi berbagai permasalahan yang muncul dalam pembelajaran mata pelajaran Matematika di kelas VII-A SMP Negeri 2 Patean adalah sebagai berikut. (1) Rendahnya keberanian siswa bertanya kepada guru dalam pembelajaran; (2) Rendahnya prestasi belajar siswa; (3) Model dan metode mengajar guru kurang bervariasi, monoton hanya mengedepankan ceramah dan tugas saja.

Untuk menghindari adanya kesalahan dalam penafsiran dan interpretasi dalam penelitian ini perlu diberikan batasan istilah-istilah sebagai berikut. (1) Keberanian siswa bertanya adalah siswa berani mengajukan pertanyaan kepada guru untuk menebak bangun datar (segitiga atau segiempat) dalam permainan KSD. Keberanian siswa bertanya dikategorikan dalam 4 kategori yaitu sangat berani, berani, cukup berani, tidak berani; (2) Prestasi Belajar Siswa hasil tes akhir yang dilakukan pada akhir siklus baik Siklus I maupun Siklus II. (3) Media Permainan KSD adalah media pembelajaran yang peneliti buat hasil modifikasi permainan Kuis Siapa Dia yang ditayangkan oleh 
stasiun TV Nasional, menebak bangun datar (segitiga atau segiempat) yang diletakkan dalam tempat khusus (dibuat dari kardus) dengan cara mengajukan pertanyaan-pertanyaan kepada moderator (guru/peneliti). Jika tebakan benar mendapat skor 5 tebakan salah mendapat skor 1.

Berdasarkan latar belakang, identifikasi, dan pembatasan masalah yang telah diuraikan, rumusan masalah dalam penelitian ini sebagai berikut. (1) Apakah pembelajaran TPS berbantuan media permainan KSD pada materi segitiga dan segiempat dapat meningkatkan keberanian siswa bertanya dan prestasi belajar siswa kelas VII-A SMP Negeri 2 Patean Semester II Tahun Pelajaran 2014/2015?; (2) Apakah pembelajaran TPS berbantuan media permainan KSD pada materi segitiga dan segiempat bagi siswa kelas VII-A SMP Negeri 2 Patean Semester II Tahun Pelajaran 2014/2015 dapat mencapai ketuntasan yang diprogram?

Tujuan yang ingin peneliti capai melalui penelitian tindakan kelas ini adalah sebagai berikut. (1) Untuk memperoleh deskripsi tentang pembelajaran TPS berbantuan media permainan KSD pada materi segitiga dan segiempat yang dapat meningkatkan keberanian siswa bertanya dan prestasi belajar siswa kelas VII-A SMP Negeri 2 Patean Semester II Tahun Pelajaran 2014/2015; (2) Untuk meningkatan keberanian siswa bertanya dan prestasi belajar siswa dengan pembelajaran TPS berbantuan media permainan KSD pada materi segitiga dan segiempat bagi kelas VII-A SMP Negeri 2 Patean Semester II Tahun Pelajaran 2014/2015; (3) Untuk mencapai ketuntasan belajar siswa dengan pembelajaran TPS berbantuan media permainan KSD pada materi segitiga dan segiempat bagi siswa kelas VII-A SMP Negeri 2 Patean Semester II Tahun Pelajaran 2014/2015.

Manfaat teoritis dari penelitian tindakan kelas ini adalah diperoleh panduan implementasi dan panduan praktik pembelajaran TPS berbantuan media permainan KSD untuk meningkatkan keberanian siswa bertanya dan prestasi belajar siswa pada materi segitiga dan segiempat siswa kelas VII-A SMP Negeri 2 Patean Semester II Tahun Pelajaran 2014/2015.

Manfaat praktis dari penelitian tindakan kelas ini antara lain sebagai berikut. (1) Bagi Siswa antara lain (a) keberanian siswa bertanya kepada guru meningkat; (b) prestasi belajar siswa meningkat; (2) Bagi Guru adalah guru mampu menciptakan proses pembelajaran matematika di kelas yang tidak lagi berjalan monoton tetapi penuh inovasi dan kreasi sehingga siswa aktif, kreatif, dan senang mengikuti pembelajaran; (3) Bagi SMP Negeri 2 Patean adalah pembelajaran TPS berbantuan media permainan KSD untuk meningkatkan keberanian siswa bertanya dan prestasi belajar siswa pada materi segitiga dan segiempat dapat digunakan oleh sekolah untuk mendorong guru Matematika yang lain bahkan guru mata pelajaran lainnya untuk melakukan kajian atau penelitian lanjutan; (4) Bagi Perpustakaan SMP Negeri 2 Patean adalah laporan Penelitian Tindakan Kelas ini dapat dijadikan tambahan referensi perpustakaan untuk bahan penelitian bagi guru; (5) Manfaat bagi MGMP Matematika SMP Kabupaten Kendal adalah penelitian ini mampu menginspirasi guru-guru Matematika yang lain untuk melakukan penelitian tindakan kelas sehingga prestasi belajar siswa se-Kabupaten Kendal dapat meningkat, mutu pendidikan pada umumnya dapat meningkat pula.

Pembelajaran TPS dikembangkan oleh Frank Lyman atau Think Pair Square dikembangkan oleh Spencer Kagan sebagai struktur kegiatan pembelajaran Cooperative Learning (Lie, 2010: 57). Pembelajaran TPS merupakan bagian dari model pembelajaran kooperatif yang berprinsip PAIKEM (Pembelajaran yang Aktif, Inovatif, Kreatif, dan Menyenangkan). Seperti namanya "Thinking", pembelajaran diawali dengan guru mengajukan pertanyaan atau isu yang terkait dengan pelajaran untuk dipikirkan oleh peserta didik. Guru memberi kesempatan kepada mereka memikirkan jawabannya. Selanjutnya, "Pairing" pada tahap ini guru meminta peserta didik untuk berpasangpasangan. Beri kesempatan kepada pasangan-pasangan itu untuk berdiskusi. Diharapkan diskusi ini 
dapat memperdalam makna dari jawaban yang telah dipikirkannya melalui intersubjektif dengan pasangan-pasangannya. Hasil diskusi intersubjektif di tiap-tiap pasangan hasilnya dibicarakan dengan pasangan seluruh kelas. Tahap ini dikenal dengan "Sharing". Dalam kegiatan ini diharapkan terjadi tanya jawab yang mendorong pada pengontruksian pengetahuan secara integratif. Peserta didik dapat menemukan struktur pengetahuan yang dipelajarinya (Suprijono, 2010, hal. 91). Dalam penelitian tindakan kelas ini, langkah-langkah Pembelajaran Kooperatif Think Pair Share sebagai berikut. a) Guru menyampaikan inti materi dan kompetensi yang akan dicapai; b) Peserta didik diminta untuk berpikir (think) tentang materi/permasalahan yang disampaikan guru; c) Peserta didik diminta untuk berpasangan (pair) dengan teman sebelahnya (kelompok 2 orang) dan mengutarakan/berbagi (share) hasil pemikiran masing-masing; d) Guru memimpin pleno kecil diskusi, tiap-tiap kelompok mengemukakan hasil diskusinya; e) Berawal dari kegiatan tersebut guru mengerahkan pembicaraan pada pokok permasalahan dan menambah materi yang belum diungkapkan para peserta didik; f) Penutup (Kementerian Pendidikan Nasional, 2010).

Media pembelajaran adalah segala sesuatu (fisik) yang dapat menyampaikan informasi atau pesan pembelajaran, merangsang pikiran, perasaan, dan perhatian penerima pesan (siswa) sehingga tercipta bentuk-bentuk komunikasi atau proses pembelajaran. Media pembelajaran tidak hanya berfungsi sebagai sebagai alat bantu guru dalam pembelajaran melainkan upaya untuk membantu siswa belajar baik individual maupun kelompok (Purwanti, 2003, hal. 5). Media visual berfungsi untuk menyalurkan pesan pembelajaran dari sumber pesan (guru) ke penerima pesan (siswa). Pesan yang disampaikan dituangkan ke dalam lambang-lambang komunikasi visual. Saluran yang dipergunakan menyangkut indera penglihatan. Beberapa kelebihan dari media visual adalah a) pesan yang disampaikan lebih menarik perhatian padahal unsur perhatian sangat penting dalam proses pembelajaran, karena dengan adanya perhatian tiimbul motivasi untuk belajar, b) pesan yang disampaikan lebih efisien, gambaran visual dapat mengkomunikasikan pesan dengan cepat dan nyata, oleh karena itu dapat mempercepat pemahaman pesan secara komprehensif, c) pesan yang disampaikan lebih efektif karena penyajian melalui visual dapat membuat siswa lebih konsentrasi Media visual antara lain gambar atau foto, chart, chart pohon (tree chart), chart identifikasi, bagan garis waktu (time line chart), grafik (graphs), media transparansi (OHP) (Purwanti, 2003, hal. 13).

Kuis Siapa Dia (disingkat KSD) adalah salah satu acara kuis Indonesia ciptaan Ani Sumadi. Acara ini ditayangkan di TVRI pada tahun 1992 s.d. 1998 dengan pembawa acara Aom Kusman. Setelah 15 tahun tidak tayang, acara ini kembali ditayangkan di TVRI sejak bulan Maret 2013 sampai Agustus 2013 dengan pembawa acara Denny Chandra dan sekarang pindah ke Trans 7 dengan pembawa acara Ananda Omesh. Kuis seperti ini pertama diperkenalkan dengan nama what's my line yang di siarkan di Amerika Serikat pertama pada era 1950an hingga 1970an. Dan setelah itu, beberapa negara mulai mengadopsi kuis-kuis serupa di televisi-televisi negara tersebut termasuk Indonesia. Regulasi permainan sebagai berikut. a) Ada 3 babak dalam setiap episodenya; b) Di setiap babak, para panelis yang berjumlah 4 orang harus menebak profesi dari mystery guest yang dihadirkan; c) Panelis berhak bertanya apa saja kepada mystery guest dalam waktu 10 menit; d) Mystery guest hanya berhak menjawab dengan jawaban ya, tidak, bisa ya, bisa tidak; e) Setelah waktu 10 menit habis, panelis harus memberikan jawaban akhir atas profesi dari mystery guest; f) Jika jawaban akhir panelis ternyata benar, maka masing-masing panelis berhak memperoleh hadiah barang atau uang tunai; g) Jika jawaban akhir panelis ternyata salah, maka mystery guest berhak memperoleh hadiah barang atau uang tunai; h) Hadiah akan disembunyikan di balik angka 19 dalam matriks 3×3 pada layar monitor (http://id.wikipedia.org/wiki/Siapa_Dia\% 3F_\%28kuis\%29). 
Media Permainan KSD pada penelitian tindakan kelas ini adalah media pembelajaran yang peneliti buat hasil modifikasi permainan Kuis Siapa Dia yang ditayangkan oleh stasiun TV Nasional dengan menebak bangun datar (segitiga atau segiempat) yang diletakkan dalam tempat khusus (dibuat dari kardus) dengan cara mengajukan pertanyaan-pertanyaan kepada moderator (guru/peneliti). Jika tebakan benar mendapat skor 5 tebakan salah mendapat skor 1. Manfaat dari media permainan KSD adalah a) mengeksplorasi kemampuan siswa tentang macam-macam segitiga menurut besar sudut dan panjang sisinya; b) mengeksplorasi kemampuan siswa tentang macammacam segiempat dengan mengidentifikasi sifat-sifatnya. Bahan dan alat untuk membuatnya antara lain kardus, kalender, lem, penggaris, gunting, dan cutter.

Langkah-langkah Permainan KSD untuk Permainan KSD Berkelompok adalah sebagai berikut. a) Guru mengajukan pertanyaan pembuka seperti (siswa diminta menunjukkan jari sebelum menjawab) misalnya "Siapa kalau sore hari nonton TV?"; "Siapa pang pernah nonton acara Kuis Siapa Dia?"; "Di stasiun TV mana kuis Siapa Dia? Ditayangkan?"; b) Guru menyampaikan bahwa pembelajaran kali ini dengan permainan Kuis Siapa Dia? (KSD), yang ditebak bukan orang tapi bangun datar segitiga dan segiempat; c) Guru menunjukkan segitiga (atau segiempat) dengan mngajukan pertanyaan Siapa Dia?. Untuk mengembangkan budaya sopan santun dan tertib siswa diminta menunjukkan jari sebelum menjawab; d) Guru meminta siswa menyiapkan ringkasan materi segitiga (atau segiempat) yang sudah dibuat pada pertemuan sebelumnya. Form Lembar Kerja Siswa Ringkasan Materi seperti contoh di bawah ini; e) Guru membagikan Kartu Pertanyaan Kelompok. Kartu Pertanyaan digunakan untuk menulis pertanyaan-pertanyaan yang akan diajukan kepada moderator; f) Guru memberikan kesempatan kepada masing-masing kelompok untuk mengajukan satu pertanyaan kepada moderator (secara bergiliran setiap anggota kelompok wajib mengajukan minimal satu pertanyaan kepada moderator. Apabila tidak mengajukan pertanyaan maka kelompok tersebut mendapat nilai negatif 1). Kegiatan ini untuk melatih siswa berani mengajukan pertanyaan-pertanyaan; g) Apabila semua anggota dalam kelompok sudah mengajukan pertanyaan-pertanyaan, maka moderator mengunci permainan. Masing-masing kelompok diminta untuk berdiskusi menentukan Siapa Dia? dalam kotak. Apabila jawaban benar mendapat skor 5, apabila jawaban salah mendapat skor 0. Guru mencatat perolehan skor pada lembar catatan perolehan skor; h) Lembar Resume saling dipertukarkan, jawaban dikoreksi oleh kelompok lain. Perwakilan kelompok (digilir sehingga semua anggota dalam satu kelompok menyampaikan jawaban kelompok). Kegiatan ini untuk melatih siswa berani mengemukan pendapat.

Untuk permainan KSD untuk individu langkah-langkah permainan KSD seperti langkahlangkah permainan KSD kelompok di atas, hanya pada langkah e) guru membagikan Kartu Pertanyaan Individu; f) Guru memberikan kesempatan kepada masing-masing siswa untuk mengajukan satu pertanyaan kepada moderator. Apabila tidak mengajukan pertanyaan maka siswa tersebut mendapat nilai -1); g) Apabila semua siswa sudah mengajukan pertanyaan-pertanyaan, maka moderator mengunci permainan. Masing-masing siswa diminta untuk menentukan Siapa Dia? dalam kotak dengan cara menuliskan jawabannya pada Kartu Pertanyaan. Apabila jawaban benar mendapat skor 5, apabila jawaban salah mendapat skor 0; dan h) Lembar Resume siswa saling dipertukarkan dengan teman satu meja, jawaban dikoreksi oleh siswa lain (Mustakim, 2015).

Keberanian adalah keadaan (sifat-sifat) berani, kegagahan mempunyai hati yang mantap dan rasa percaya diri yang besar dalam menghadapi bahaya, kesulitan dan sebagainya: tidak tahu (gentar, kecut) (Mulyono, 1995). Bertanya yang dilakukan siswa di kelas membutuhkan keberanian, karena tanpa keberanian kegiatan bertanya pada guru di kelas akan mengalami hambatan. Adapun pengertian bertanya adalah meminta keterangan (penjelasan): meminta supaya diberitahu (tentang 
sesuatu), kalau tidak tahu (Mulyono, 1995). Jadi bisa diartikan jika bertanya adalah suatu kegiatan yang dilakukan seseorang untuk meminta keterangan dan untuk memperoleh jawaban yang lebih jelas atas sesuatu yang belum dimengerti atau belum dipahami.

Sehingga dapat disimpulkan bahwa keberanian bertanya adalah keadaan atau sifat-sifat yang ada pada setiap individu yang ditunjukkan dengan adanya kemampuan untuk maju mencoba dengan rasa percaya diri dan mampu untuk mengatasi rasa takut ketika meminta keterangan dan memperoleh jawaban yang jelas atas sesuatu yang belum dipahami. Selain itu bertanya dalam pembelajaran dipandang sebagai kegiatan guru untuk mendorong, membimbing dan menilai kemampuan berfikir siswa. Bagi siswa bertanya merupakan bagian penting dalam proses belajar mengajar karena siswa dapat menggali informasi, mengkonfirmasikan apa yang sudah diketahui, dan mengarahkan perhatian pada aspek yang belum diketahuinya.

Ada beberapa faktor yang membuat siswa enggan atau tidak berani bertanya, diantaranya adalah a) Takut dianggap bodoh atau ditertawakan teman; b) Takut disuruh maju menyelesaikan soal ke depan oleh guru; c) Takut jika diminta menjelaskan ulang materi yang baru saja disampaikan oleh guru; d) Tidak membaca materi pelajaran atau kurang memperhatikan guru saat pelajaran sehingga sama sekali tidak paham materi yang akan ditanyakan; e) Takut mengemukakan pendapat karena bingung cara menyampaikannya (tidak dapat berbahasa dengan baik). Keberanian siswa bertanya dalam penelitian ini adalah siswa berani mengajukan pertanyaan kepada guru untuk menebak bangun datar (segitiga atau segiempat) dalam permainan KSD. Keberanian siswa bertanya dikategorikan dalam 4 kategori yaitu sangat berani, berani, cukup berani, tidak berani. Selengkapnya pada Tabel 1 berikut.

Tabel 1. Kategori Keberanian Siswa Bertanya

\begin{tabular}{ll}
\hline Kategori & Keterangan \\
\hline Sangat Berani & Mengajukan 3 pertanyaan kepada guru \\
Berani & Mengajukan 2 pertanyaan kepada guru \\
Cukup Berani & Mengajukan 1 pertanyaan kepada guru \\
Tidak Berani & Tidak pernah mengajukan pertanyaan kepada guru \\
\hline
\end{tabular}

Pakar pendidikan mengemukakan pengertian yang berbeda antara satu dengan yang lainnya, namun demikian tetap mengacu pada prinsip yang sama yaitu setiap orang yang melakukan proses belajar akan mengalami suatu perubahan dalam dirinya. Gagne mendefinisikan belajar adalah perubahan disposisi atau kemampuan yang dicapai seseorang melalui aktivitas, perubahan disposisi tersebut bukan diperoleh langsung dari proses pertumbuhan secara alamiah. Travers, belajar adalah perubahan perilaku sebagai hasil dari pengalaman. Harold Spears, belajar adalah mengamati, membaca, meniru, mencoba sesuatu, mendengar, dan mengikuti arah tertentu. Geoch, belajar adalah perubahan penampilan sebagai hasil latihan. Morgan, belajar adalah perubahan perilaku yang bersifat permanen sebagai hasil dari pengalaman. Dari beberapa pendapat di atas, belajar dapat disimpulkan sebagai kegiatan psiko-fisik-sosio menuju ke perkembangan pribadi seutuhnya (Suprijono, 2010, hal. 3).

Untuk mengetahui berhasil tidaknya seseorang dalam belajar maka perlu dilakukan suatu evaluasi yang bertujuan untuk mengetahui berhasil tidaknya siswa setelah mengikuti proses pembelajaran. Hasil evaluasi dapat memperlihatkan tinggi rendahnya keberhasilan belajar siswa. Menurut Suprijono (2010: 5), hasil belajar adalah pola-pola perbuatan, nilai-nilai, pengertian- 
pengertian, sikap-sikap, apresiasi dan keterampilan. Menurut Gagne, hasil belajar meliputi informasi verbal, keterampilan intelektual, strategi kognitif, keterampilan motorik, dan sikap. Menurut Bloom, hasil belajar mencakup kemampuan kognitif, afektif, dan psikomotorik. Domain kognitif adalah knowledge (pengetahuan), comprehension (pemahaman, menjelaskan, meringkas, contoh), application (menerapkan), analysis (menguraikan, menentukan hubungan), synthesis (mengorganisasikan, merencanakan, membentuk bangunan baru), dan evaluation (menilai). Domain efektif adalah receiving (sikap menerima), responding (memberikan respon), valuing (nilai), organization (organisasi), characterization (karakterisasi), rountinized (rutin). Domain psikomotor mencakup keterampilan produktif, teknik fisik, sosial, manajerial, dan intelektual. Menurut Lindgren, hasil belajar meliputi kecakapan, informasi, pengertian, dan sikap. Jadi dapat disimpulkan bahwa hasil belajar adalah perubahan perilaku secara keseluruhan bukan hanya salah satu aspek potensi kemanusiaan saja. Artinya hasil belajar tidak dilihat secara fragmentasi atau terpisah, melainkan komprehensif (Suprijono, 2010, hal. 7).

Prestasi adalah kemampuan seseorang dalam menyelesaikan suatu kegiatan, secara singkat dapat dikatakan prestasi adalah hasil usaha. Perbedaan hasil belajar dengan prestasi belajar, bahwa penilaian hasil belajar dilakukan sekali setelah suatu kegiatan pembelajaran dilaksanakan, sementara penilaian prestasi belajar dilakukan setelah beberapa kali penilaian hasil belajar dan hasil belajar yang terakhir dianggap sebagai prestasi belajar karena diharapkan merupakan hasil yang maksimal, tetapi kedua istilah tersebut dikatakan identik karena sama-sama merupakan hasil usaha yaitu belajar.

Penilaian prestasi belajar adalah kegiatan yang bertujuan untuk mengetahui sejauh mana proses belajar dan pembelajaran telah berjalan secara efektif. Keefektifan pembelajaran tampak pada kemampuan siswa mencapai tujuan belajar yang telah ditetapkan. Dari segi guru, penilaian prestasi belajar akan memberikan gambaran mengenai keefektifan mengajarnya, apakah pendekatan dan media yang digunakan mampu membantu siswa mencapai tujuan belajar yang ditetapkan. Tes prestasi belajar yang dilakukan oleh setiap guru dapat memberikan informasi sampai dimana penguasaan dan kemampuan yang telah dicapai siswa dalam mencapai tujuan pembelajaran tersebut.

Prestasi belajar dapat dilihat secara nyata berupa skor atau nilai setelah siswa mengerjakan suatu tes atau ulangan. Tes atau ulangan yang digunakan untuk menentukan prestasi belajar merupakan alat untuk mengukur aspek-aspek tertentu dari siswa misalnya pengetahuan, pemahaman atau aplikasi suatu konsep. Prestasi siswa pada mata pelajaran matematika dipengaruhi oleh faktor dari dalam diri siswa yang belajar meliputi $\mathrm{IQ}$, motivasi, minat, bakat, kesehatan dan faktor luar siswa yang belajar yang meliputi guru, materi ajar, latihan, sarana kelengkapan belajar siswa, tempat di sekolah atau di rumah serta di lingkungan sosial siswa. Dalam penelitian ini, prestasi belajar siswa diperoleh dari hasil ulangan akhir siklus yang dilakukan pada baik Siklus I maupun Siklus II.

Dalam penelitian tindakan kelas ini hanya fokus pada sifat-sifat segitiga dan segiempat. Hal ini sesuai dengan penggunaan media pembelajaran permainan KSD yaitu untuk mengeksplorasi sifat-sifat segitiga dan segiempat yang sudah dipelajari siswa. Segitiga menurut besar sudut dan panjang sisinya adalah a) segitiga siku-siku sama kaki, b) segitiga siku-siku sembarang, c) segitiga lancip sama kaki, d) segitiga lancip sama sisi, e) segitiga lancip sembarang, f) segitiga tumpul sembarang, g) segitiga tumpul sama kaki. Sedangkan segiempat meliputi h) persegipanjang, i) persegi, j) jajargnjang, k) belah ketupat, I) layang-layang, m) trapesium. 
Sifat-sifat segitiga dan segiempat sebagai berikut (M.S. Wahyudi, dkk.2014). a) Segitiga siku-siku samakaki: salah satu sudutnya besarnya 90॰ (sudut siku-siku), dua sisinya sama panjan; b) Segitiga siku-siku sembarang: salah satu sudutnya besarnya $90^{\circ}$ (sudut siku-siku), ketiga sisinya sembarang (tidak ada yang sama panjang); c) Segitiga lancip samakaki: ketiga sudutnya besarnya kurang dari $90^{\circ}$ (sudut lancip), dua sisinya sama panjang; d) Segitiga lancip samasisi: ketiga sudutnya besarnya kurang dari $90^{\circ}$ (sudut lancip), ketiga sisinya sama panjang; e) Segitiga lancip sembarang: ketiga sudutnya besarnya kurang dari 90॰ (sudut lancip), ketiga sisinya tidak ada yang sama panjang (sembarang); f) Segitiga tumpul samakaki: salah sudutnya besarnya lebih dari 90॰ (sudut tumpul), dua sisinya sama panjang; g) Segitiga tumpul sembarang: salah sudutnya besarnya lebih dari $90^{\circ}$ (sudut tumpul), ketiga sisinya tidak ada yang sama panjang (sembarang); $h$ ) Persegi panjang: panjang sisi-sisi yang berhadapan sama dan sejajar, keempat sudutnya siku-siku, panjang diagonal-diagonalnya sama dan saling membagi dua sama panjang. dapat menempati bingkainya kembali dengan empat cara; i) Persegi: sisi-sisi yang berhadapan sejajar, keempat sudutnya sikusiku, panjang diagonal-diagonalnya sama dan saling membagi dua sama panjang, panjang keempat sisinya sama, setiap sudutnya dibagi dua sama ukuran oleh diagonal-diagonalnya, diagonaldiagonalnya berpotongan saling tegak lurus; j) Jajargenjang: sisi-sisi yang berhadapan sejajar dan sama panjang, sudut-sudut yang berhadapan sama ukuran, dua sudut yang berdekatan saling berpelurus, diagonal jajargenjang membagi daerah jajargenjang menjadi dua bagian sama besar, diagonal-diagonalnya saling membagi dua sama panjang; k) Belahketupat: semua sisinya sama panjang, sisi-sisi yang berhadapan sejajar, sudut-sudut yang berhadapan sama ukurannya, diagonaldiagonalnya membagi sudut menjadi dua ukuran yang sama ukuran, kedua diagonalnya saling tegak lurus dan saling membagi dua sama panjang, diagonal membagi belahketupat menjadi dua bagian yang sama besar atau diagonal-diagonalnya merupakan sumbu simetri, jumlah ukuran dua sudut yang berdekatan $180^{\circ}$; I) Layang-layang: panjang dua sisi berdekatan sama, sepasang sudut yang berhadapan ukuran, salah satu diagonalnya membagi layang-layang menjadi dua ukuran yang sama, diagonal-diagonalnya saling tegak lurus dan salah satu diagonalnya membagi diagonal yang lain menjadi dua sama panjang; m) Trapesium: sepasang sisi yang berhadapan sejajar, jumlah ukuran dua sudut yang berdekatan antara dua sisi sejajar adalah $180^{\circ}$, pada trapesium sama kaki ukuranukuran sudut alasnya sama, panjang diagonal-diagonalnya sama, dan menempati bingkainya dengan dua cara), pada trapesium siku-siku mempunyai tepat dua sudut siku-siku).

Beberapa penelitian yang dilakukan untuk melatih dan meningkatkan keberanian siswa bertanya misalnya yang dilakukan oleh Marion Reba'i (2006) dengan menggunakan kartu pertanyaan. Siswa mengajukan pertanyaan ditulis pada kartu pertanyaan kemudian kartu diberikan kepada guru. Sedangkan Amin Subhan, Siska Desy Fatmaryanti, dan Nur Hidayati (2013) menggunakan model pembelajaran aktif tipe Card Sort yang akan menggugah semangat dan antusias siswa dalam bertanya melalui kerja kelompok memilah kartu, menemukan pasangan, berdiskusi mengemukakan pendapat dan membuat pertanyaan untuk kelompok lain.

Menurut Wahyudin (2008: 40) penggunaan strategi permainan sewaktu-waktu di ruang kelas antara lain (1) Jika dirancang dengan tepat, permainan dapat bermanfaat bagi siswa-siswa yang mengalami masalah belajar tertentu misalnya kelemahan dalam berbahasa (keterampilanketerampilan membaca atau verbal); (2) Permainan dapat digunakan untuk membantu siswa-siswa yang memperlihatkan masalah disiplin yang disebabkan kebosanan dengan rutinitas ruang kelas; (3) Permainan sangat sesuai di ruang kelas yang menggunakan pendekatan laboratorium atau pusat belajar. Hal ini mungkin ketika permainan diatur sedemikian hingga berjalan terlepas dari kendali guru secara langsung; (4) Permainan memberi kesempatan kepada para siswa untuk menerapkan 
kendali dan pengaruh terhadap lingkungan sosial mereka dengan memungkinkan pergeseran peran dari pengguna informasi yang pasif menjadi pembuat keputusan yang aktif; (5) Permainan dapat mengangkat interaksi-interaksi sosial yang menguntungkan di antara sesama siswa dengan mendorong terjadinya kerjasama dan diskusi; (6) Permainan dapat menyediakan informasi diagnostik bagi guru, yang dapat digunakannya untuk membantu para siswa memperbaiki miskonsepsi dan mengisi celah dalam struktur belajar mereka; (7) Permainan dapat digunakan untuk mengintegrasikan matematika dengan bidang-bidang studi lainnya dan dapat pula diarahkan sesuai dengan minat khusus siswa.

Pentingnya menguasai matematika ternyata tidak membuat siswa mempelajari matematika dengan aktif, inovatif, kreatif, dan senang. Kebanyakan siswa menganggap belajar matematika adalah aktivitas yang membosankan, tidak menyenangkan, duduk berjam-jam dengan mencurahkan perhatian dan pikiran pada suatu materi pelajaran matematika, baik yang sedang disampaikan guru maupun yang sedang dihadapi di meja belajar. Kegiatan ini hampir selalu dirasakan sebagai beban daripada upaya aktif untuk memperoleh ilmu. Bahkan komentar klasik siswa terhadap mata pelajaran matematika adalah "pelajaran sulit" sehingga berakibat prestasi belajar siswa rendah. Kondisi seperti ini terjadi karena guru dalam melakukan pembelajaran di kelas masih menggunakan model dan metode mengajar kurang bervariasi, monoton hanya mengedepankan ceramah dan tugas saja apalagi memberi tugas yang menantang bagi sisa untuk mencoba cara lain atau bahkan menemukan cara sendiri yang tetap logis. Pembelajaran TPS merupakan bagian dari model pembelajaran kooperatif yang berprinsip PAIKEM (Pembelajaran yang Aktif, Inovatif, Kreatif, dan Menyenangkan). "Thinking" pembelajaran diawali dengan guru mengajukan pertanyaan atau isu yang terkait dengan pelajaran untuk dipikirkan oleh peserta didik. Guru memberi kesempatan kepada mereka memikirkan jawabannya. "Pairing" pada tahap ini guru meminta peserta didik untuk berpasang-pasangan. Beri kesempatan kepada pasangan-pasangan itu untuk berdiskusi. Diharapkan diskusi ini dapat memperdalam makna dari jawaban yang telah dipikirkannya melalui intersubjektif dengan pasanganpasangannya. Hasil diskusi intersubjektif di tiap-tiap pasangan hasilnya dibicarakan dengan pasangan seluruh kelas. Tahap ini dikenal dengan "Sharing". Dalam kegiatan ini diharapkan terjadi tanya jawab yang mendorong pada pengontruksian pengetahuan secara integratif. Peserta didik dapat menemukan struktur pengetahuan yang dipelajarinya.

Media pembelajaran adalah segala sesuatu (fisik) yang dapat menyampaikan informasi atau pesan pembelajaran, merangsang pikiran, perasaan, dan perhatian penerima pesan (siswa) sehingga tercipta bentuk-bentuk komunikasi atau proses pembelajaran. Media pembelajaran tidak hanya berfungsi sebagai sebagai alat bantu guru dalam pembelajaran melainkan upaya untuk membantu siswa belajar baik individual maupun kelompok. Media pembelajaran Permainan KSD dengan tanya jawab antara siswa dan guru digunakan untuk (1) mengeksplorasi kemampuan siswa tentang macam-macam segitiga menurut besar sudut dan panjang sisinya; (2) mengeksplorasi kemampuan siswa tentang macam-macam segiempat dengan mengidentifikasi sifat-sifatnya. Sehingga penerapan pembelajaran TPS berbantuan media permainan KSD dapat meningkatkan keberanian siswa bertanya dan prestasi belajar siswa kelas VII-A SMP Negeri 2 Patean materi segitiga dan segiempat Semester II Tahun Pelajaran 2014/2015.

Berdasarkan uraian di atas, hipotesis tindakan dalam penelitian tindakan kelas ini adalah sebagai berikut. (1) Pembelajaran TPS berbantuan media permainan KSD pada materi segitiga dan segiempat diduga dapat meningkatkan keberanian siswa bertanya dan prestasi belajar siswa kelas VII-A SMP Negeri 2 Patean Semester II Tahun Pelajaran 2014/2015; (2) Pembelajaran TPS berbantuan media permainan KSD pada materi segitiga dan segiempat bagi siswa kelas VII-A SMP 
Negeri 2 Patean Semester II Tahun Pelajaran 2014/2015 diduga dapat mencapai ketuntasan yang diprogram.

Penelitian dilakukan pada kelas VII-A Semester II Tahun Pelajaran 2014/2015 karena dari hasil pengamatan dan pengalaman peneliti mengajar di empat kelas paralel, keberanian siswa bertanya serta prestasi belajar siswa kelas VII-A adalah paling rendah.

Pihak yang yang terlibat dalam penelitian ini adalah sebagai berikut. (1) Subjek penelitiannya adalah siswa kelas VII-A SMP Negeri 2 Patean Kendal Semester II Tahun Pelajaran 2014/2015. Jumlah siswa 27 terdiri dari 16 siswa laki-laki dan 11 siswa perempuan; (2) Objek penelitiannya adalah peningkatan keberanian siswa bertanya dan prestasi belajar matematika siswa pada materi segitiga dan segiempat; (3) Penelitian juga melibatkan guru mata pelajaran matematika yang lain sebagai pengamat atau kolaborator yaitu guru matematika kelas VIII.

Sumber data dapat berasal dari subjek penelitian dan dari bukan subjek penelitian. Sumber data dari subjek penelitian merupakan sumber data primer yaitu nilai ulangan harian pada Siklus I atau Siklus II. Sumber data dari selain subjek penelitian merupakan sumber data sekunder yaitu data hasil pengamatan yang dilakukan oleh teman sejawat untuk keberanian siswa bertanya.

Ada dua macam data yang diperoleh dalam penelitian tindakan kelas ini yaitu: (1) Data Kuantitatif diperoleh melalui ulangan harian pada Siklus I dan Siklus II untuk mengungkap prestasi belajar siswa. Soal terdiri dari soal uraian dengan tiap-tiap soal mempunyai bobot skor berbeda. (2) Data Kualitatif berupa keberanian siswa bertanya serta respon siswa terhadap proses pembelajaran selama dan sesudah pembelajaran berlangsung. Dalam penelitian tindakan kelas ini terdapat enam data yang akan dikumpulkan, dianalisis dan sebagai bahan diskusi selengkapnya pada Tabel 2 berikut ini.

Tabel 2. Data Penelitian

\begin{tabular}{lccc}
\multicolumn{1}{c}{ Data } & Kondisi Awal & Siklus I & Siklus II \\
\hline Keberanian siswa bertanya & $\sqrt{ }$ & $\sqrt{ }$ & $\sqrt{ }$ \\
Prestasi belajar siswa & $\sqrt{ }$ & $\sqrt{ }$ & $\sqrt{ }$ \\
\hline
\end{tabular}

Dalam penelitian tindakan kelas dibutuhkan data-data yang dapat dianalisis dan direfleksikan sehingga terbentuk sebuah perencanaan tindakan untuk memperbaiki kondisi awal. Berikut ini dijelaskan teknik pengumpulan data serta alat pengumpulan data. Teknik pengumpulan data. Teknik pengumpulan data adalah teknik untuk memperoleh data tentang keberanian siswa bertanya dan prestasi belajar siswa. Ada 2 macam teknik yaitu (a) Teknik tes (tes tertulis); (b) Teknik non tes (pengamatan, dokumentasi).

Alat Pengumpulan Data tergantung pada teknik yang digunakan. Alat pengumpulan data untuk memperoleh data tentang keberanian siswa bertanya dan prestasi belajar siswa. (a) Teknik tes, alat pengumpulan data dengan teknik tes berupa butir soal tes. Terdiri dari Tes Siklus I dan Tes Siklus II. Tes Siklus I diberikan kepada siswa setelah dilakukan tindakan pada Siklus I, digunakan untuk mengetahui prestasi belajar siswa setelah dilakukan tindakan pada Siklus I. Tes Siklus II diberikan kepada siswa setelah dilakukan tindakan pada Siklus II, digunakan untuk mengetahui prestasi belajar siswa setelah dilakukan tindakan pada Siklus II; (b) Teknik non tes, alatnya pengumpulan data untuk teknik non tes berbentuk: (1) Pedoman dan Lembar Observasi, digunakan untuk mengamati dan memperoleh data keberanian siswa bertanya; (2) Pedoman dan Lembar Wawancara, digunakan untuk mengetahui respon siswa terhadap pembelajaran yang dilakukan oleh peneliti; (3) Jurnal Pembelajaran yang dibuat oleh guru berisi catatan-catatan penting selama proses 
pembelajaran. Alat ini digunakan oleh peneliti setiap kali selesai mengimplementasikan tindakan. Jurnal tersebut dijadikan sebagai bahan refleksi diri bagi peneliti untuk mengungkap aspek: (1) respon siswa terhadap pembelajaran; (2) situasi pembelajaran; dan (3) kekurangpuasan peneliti terhadap pelaksanaan tindakan yang telah dilakukan.

Untuk memperjelas uraian di atas, teknik dan alat pengumpulan data dalam penelitian tindakan kelas ini dapat dirangkum seperti Tabel 3 berikut ini.

Tabel 3. Teknik dan Alat Pengumpulan Data

\begin{tabular}{lllll}
\hline \multicolumn{1}{c}{ Data } & & \multicolumn{1}{c}{ Kondisi Awal } & \multicolumn{1}{c}{ Siklus I } & \multicolumn{1}{c}{ Siklus II } \\
\hline $\begin{array}{l}\text { Keberanian siswa } \\
\text { bertanya }\end{array}$ & Teknik & Dokumentasi & Observasi & Observasi \\
\cline { 2 - 5 } & Alat & $\begin{array}{l}\text { Jurnal Pembelajaran } \\
\text { Guru }\end{array}$ & $\begin{array}{l}\text { Instrumen Lembar } \\
\text { Observasi }\end{array}$ & $\begin{array}{l}\text { Instrumen Lembar } \\
\text { Observasi }\end{array}$ \\
\hline $\begin{array}{l}\text { Prestasi Belajar } \\
\begin{array}{l}\text { Siswa } \\
$\cline { 2 - 4 }\end{array}\end{array} & Teknik & Dokumentasi & Tes & Tes \\
\cline { 2 - 5 } & Alat & $\begin{array}{l}\text { Daftar Nilai Ulangan } \\
\text { Harian }\end{array}$ & Butir Soal Tes Siklus I & $\begin{array}{l}\text { Butir Soal Tes Siklus } \\
\text { II }\end{array}$ \\
\hline
\end{tabular}

Validasi diperlukan agar diperoleh data yang valid (cocok, sesuai dengan kenyataan, syah). Data yang divalidasi adalah tentang keberanian siswa bertanya dan prestasi belajar siswa.

1. Validasi data keberanian siswa bertanya baik Siklus I maupun Siklus II yang dikumpulkan dengan teknik observasi menggunakan instrumen lembar observasi, agar diperoleh data yang valid perlu dilakukan validasi dengan cara melibatkan observer/pengamat teman sejawat yang dikenal dengan cara kolaborasi.

2. Validasi data prestasi belajar matematika siswa baik Siklus I maupun Siklus II yang dikumpulkan dengan teknik tes tertulis, agar diperoleh data yang valid perlu divalidasi butir soalnya dengan cara membuat kisi-kisi butir soal sebelum soal dibuat.

Untuk memperjelas uraian di atas, validasi data dalam penelitian tindakan kelas ini dapat dirangkum seperti pada Tabel 4.

Tabel 4. Validasi Data Penelitian

\begin{tabular}{|c|c|c|c|c|}
\hline Data & & Siklus I & Siklus II & Validasi Data \\
\hline \multirow[b]{2}{*}{$\begin{array}{l}\text { Keberanian } \\
\text { siswa bertanya }\end{array}$} & Teknik & Observasi & Observasi & \multirow{2}{*}{$\begin{array}{l}\text { Kolaborasi dengan } \\
\text { teman sejawat sebagai } \\
\text { observer/pengamat }\end{array}$} \\
\hline & Alat & $\begin{array}{l}\text { Instrumen Lembar } \\
\text { Observasi }\end{array}$ & $\begin{array}{l}\text { Instrumen Lembar } \\
\text { bservasi }\end{array}$ & \\
\hline \multirow{2}{*}{$\begin{array}{l}\text { Prestasi Belajar } \\
\text { Siswa }\end{array}$} & Teknik & Tes Tertulis & Tes Tertulis & \multirow{2}{*}{ Kisi-kisi Butir Soal Tes } \\
\hline & Alat & Butir Soal Tes Siklus I & Butir Soal Tes Siklus II & \\
\hline
\end{tabular}

\section{Analisis Data Keberanian Siswa Bertanya}

Terdapat 3 data untuk variabel keberanian siswa bertanya yaitu kondisi awal (prasiklus), Siklus I, dan Siklus II dianalisis menggunakan teknik deskripif komparatif dilanjutkan dengan analisis kritis dengan merefleksi. Deskriptif yaitu membandingkan secara deskripsi data keberanian siswa bertanya pada kondisi awal (prasiklus) dengan keberanian siswa bertanya pada Siklus I, membandingkan secara deskripsi data keberanian siswa bertanya pada Siklus I dengan keberanian siswa bertanya pada Siklus II, dan membandingkan secara deskripsi data keberanian siswa bertanya pada kondisi awal dengan keberanian siswa bertanya pada Siklus II. Refleksi yaitu membuat 
simpulan berdasarkan deskriptif komparatif dilanjutkan dengan memberi ulasan atau simpulan guna menentukan perlu tidaknya tindakan siklus berikutnya.

\section{Analisis Data Prestasi Belajar Matematika Siswa}

Terdapat 3 data untuk variabel prestasi belajar siswa yaitu kondisi awal (prasiklus), Siklus I, dan Siklus II dianalisis menggunakan teknik deskripif komparatif dilanjutkan dengan analisis kritis dengan merefleksi. Deskriptif yaitu membandingkan secara deskripsi data prestasi belajar siswa pada kondisi awal (prasiklus) dengan prestasi belajar siswa pada Siklus I, membandingkan secara deskripsi data prestasi belajar siswa pada Siklus I dengan prestasi belajar siswa pada Siklus II, dan membandingkan secara deskripsi data prestasi belajar siswa pada kondisi awal dengan prestasi belajar siswa pada Siklus II.

Indikator keberhasilan penelitian tindakan kelas ini sebagai berikut. (1) Indikator Kinerja Variabel Keberanian Siswa Bertanya: Lebih dari 75\% siswa keberanian siswa bertanya pada kategori berani; (2) Indikator Kinerja Variabel Prestasi Belajar Matematika Siswa: (a) Rata-rata nilai prestasi belajar siswa minimal 75; (b) Lebih dari 75\% siswa prestasi belajar mencapai batas minimal KKM yaitu 75.

Berdasarkan diskusi kolaboratif antara peneliti dengan observer/guru pengamat, seperti uraian tersebut di atas, peneliti menggunakan penelitian tindakan kelas dengan menerapkan pembelajaran TPS berbantuan media permainan KSD dalam 2 (dua) Siklus. Prosedur tindakan pembelajaran yang dilakukan adalah sebagai berikut. (1) Peneliti bersama guru pengamat berkolaborasi untuk menyiapkan materi pokok yang harus diteliti dan harus dipelajari siswa; (2) Secara kolaborasi peneliti dan guru pengamat membuat rancangan pembelajaran, media pembelajaran, instrumen evaluasi, skoring evaluasi; (3) Pada pelaksanaan pembelajaran (a) Guru menyampaikan inti materi dan kompetensi yang akan dicapai, (b) Peserta didik diminta untuk berpikir (think) tentang materi/permasalahan yang disampaikan guru dengan membuat ringkasan materi (sifat-sifat segitiga dan segiempat) pada lembar kerja siswa Ringkasan Materi, (c) Peserta didik diminta untuk berpasangan (pair) dengan teman sebelahnya (kelompok 2 orang) dan mengutarakan/berbagi (share) hasil pemikiran masing-masing dengan saling bertanya jawab, (d) Guru memimpin pleno kecil diskusi, tiap-tiap kelompok mengemukakan hasil diskusinya, (e) Berawal dari kegiatan tersebut guru mengerahkan pembicaraan pada pokok permasalahan dan menambah materi yang belum diungkapkan para peserta didik, (f) Guru melaksanakan permainan KSD; (g) Penutup; (4) Pada pembelajaran berakhir guru memberikan ulangan akhir untuk mengetahui kemampuan siswa menyelesaikan soal dengan mengerjakan soal soal uraian pada lembar jawab yang telah disediakan peneliti.

Kegiatan dirancang dengan Penelitian Tindakan Kelas. Kegiatan diterapkan dalam upaya untuk meningkatkan keberanian siswa bertanya dan prestasi belajar matematika siswa. Tahapan langkah disusun dalam siklus penelitian. Setiap siklus memiliki 4 tahapan, yaitu (1) perencanaan, (2) tindakan, (3) pengamatan, dan (4) refleksi.

\section{HASIL DAN PEMBAHASAN \\ Deskripsi Kondisi Awal}

Sebelum dilakukan tindakan 2 (dua) siklus, pembelajaran pada Standar Kompetensi (SK) 5. Memahami hubungan garis dengan garis, garis dengan sudut, sudut dengan sudut, serta menentukan ukurannya dengan Kompetensi Dasar (KD) 5.3 Membagi sudut dan Kompetensi Dasar (KD) 5.4 Membagi sudut dilaksanakan sebanyak 6 kali, 5 kali pertemuan/tata muka berdasarkan RPP 
pra-Siklus pada tanggal 14, 17, 18, 21, dan 24 April 2015 dan 1 kali ulangan akhir pra-Siklus pada tanggal 25 April 2014. Pembelajaran berlangsung kurang kondusif, guru dalam pembelajaran di kelas monoton yaitu ceramah dan tanya jawab dilanjutkan latihan soal, sehingga proses belajar mengajar tidak menarik. Akibatnya siswa jenuh dan pasif, sekedar mencatat penjelasan yang disampaikan dan dicatat di papan tulis itupun harus diingatkan dan disuruh oleh guru dengan perintah klasik "catat anak-anak jangan ribut saja", kurang inisiatif, kurang mendukung keaktifan siswa dalam pembelajaran. Pembelajaran cenderung memaksa siswa untuk mendengar dan melihat penjelasan guru, jarang melakukan kegiatan kalaupun ada kegiatan justru tidak berkaitan dengan tujuan pembelajaran. Guru jarang memberikan kesempatan kepada siswa berkreasi, pembelajaran berjalan monoton sehingga ide-ide dan pengetahuan yang dimiliki siswa tidak berkembang.

Hasil pengamatan peneliti selama mengajar di kelas VII-A pada aspek keberanian siswa bertanya diperoleh data, banyak siswa dengan keberanian bertanya kategori amat berani 2 siswa (7\%), berani 10 siswa (44\%), cukup berani 9 siswa (33\%), dan tidak berani 6 siswa (22\%). Dapat disimpulkan hanya 12 siswa (44\%) yang berani mengajukan pertanyaan kepada guru apabila menjumpai hal-hal yang menurut mereka tidak paham sehingga masih ada 15 siswa (56\%) tidak berani bertanya kepada guru dengan alasan takut, malu dikira oleh temannya sebagai siswa yang bodoh. Sedangkan prestasi belajar mereka juga belum memuaskan karena nilai tertinggi 85 , nilai terendah 40 , rata-rata nilai 59, dengan ketuntasan belajar klasikal hanya $37 \%$ artinya dari 27 siswa hanya 10 siswa yang tuntas belajar. Kondisi seperti ini terjadi karena guru dalam melakukan pembelajaran di kelas masih menggunakan model dan metode mengajar kurang bervariasi, monoton hanya mengedepankan ceramah dan tugas saja.

\section{Deskripsi Siklus I}

1. Tahap Perencanaan Tindakan. (a) Menyusun 1 (satu) RPP untuk 2 (dua) pertemuan tata muka dengan materi sifat-sifat segitiga. Pertemuan ke-1 permainan KSD untuk permainan kelompok dan Pertemuan ke-2 untuk permainan individu; (b) Menyiapkan bahan bacaan yang memuat sifat-sifat segitiga; (c) Menyiapkan lembar kerja siswa untuk membuat Ringkasan Materi tentang Sifat-Sifat Segitiga; (d) Menyiapkan soal-soal untuk ulangan akhir Siklus I; (e) Mempersiapkan lembar pengamatan untuk mengamati situasi dan kondisi kegiatan pembelajaran, yaitu lembar pengamatan untuk keberanian siswa bertanya; (f) Mempersiapkan angket respon siswa dan angket refleksi siswa dalam pembelajaran.

2. Tahap Pelaksanaan Tindakan

\section{a. Pertemuan ke-1}

Pertemuan ke-1 dilaksanakan pada hari Senin tanggal 11 Mei 2014 jam ke-2 dan ke-3 berisi penyampaian materi tentang sifat-sifat segitiga. Kemudian dilanjutkan dengan pemberian tugas, pembahasan dan penarikan kesimpulan secara bersama-sama. Semuanya dilaksanakan melalui Pembelajaran Think Pair Share (TPS) berbantuan media permainan KSD sebagai berikut. (1) Pendahuluan, (a) Guru membuka pelajaran, dilanjutkan dengan menyampaikan SK, KD, indikator dan tujuan pembelajaran, skenario pembelajaran yang akan digunakan, mendeskripsikan berbagai kebutuhan logistik penting, dan memotivasi siswa untuk terlibat dalam kegiatan pembelajaran dengan aktif dan senang; (b) Untuk memotivasi siswa, guru memberikan apersepsi pembelajaran dengan mengingatkan siswa tentang manfaat mempelajari sifat-sifat segitiga; (2) Kegiatan inti, (a) Guru menyampaikan inti materi pembelajaran yaitu sifat-sifat segitiga menurut besar sudut dan panjang sisinya;

(b) Siswa diminta untuk berpikir (think) tentang sifat-sifat sifat-sifat segitiga menurut besar 
sudut dan panjang sisinya dilanjutkan membuat ringkasan materi tentang sifat-sifat segitiga menurut besar sudut dan panjang sisinya; (c) Siswa diminta untuk berpasangan (pair) dengan teman sebelahnya (kelompok 2 orang) dan mengutarakan/berbagi (share) dengan tanya jawab berkaitan dengan hasil pemikiran masing-masing; (d) Guru memimpin pleno kecil diskusi, tiap-tiap kelompok mengemukakan hasil diskusinya; (e) Guru mengerahkan pembicaraan pada pokok permasalahan dan menambah materi yang belum diungkapkan para peserta didik; (f) Guru membagi kartu pertanyaan untuk mencatat pertanyaanpertanyaa yang akan diajukan pada permainan $\mathrm{KSD}$, dilanjutkan dengan pelaksanakan permainan KSD untuk permainan kelompok dengan masing-masing beranggotakan 4 siswa; (3) Penutup dengan kegiatan (a) Guru membantu siswa merangkum materi pelajaran; (b) Guru memberikan PR; (c) Guru memberi angket respon siswa; (d) Memberikan motivasi kepada siswa dengan memberitahukan materi yang akan dipelajari pada pertemuan selanjutnya.

b. Pertemuan ke-2

Pertemuan ke-2 dilaksanakan pada hari Jumat tanggal 15 Mei 2015 jam ke-1 dan ke-2 berisi penyampaian materi tentang sifat-sifat segitiga. Kemudian dilanjutkan dengan pemberian tugas, pembahasan dan penarikan kesimpulan secara bersama-sama. Semuanya dilaksanakan melalui Pembelajaran Think Pair Share (TPS) berbantuan media permainan KSD sebagai berikut. (1) Pendahuluan, (a) Guru membuka pelajaran, dilanjutkan dengan menyampaikan SK, KD, indikator dan tujuan pembelajaran, skenario pembelajaran yang akan digunakan, mendeskripsikan berbagai kebutuhan logistik penting, dan memotivasi siswa untuk terlibat dalam kegiatan pembelajaran dengan aktif dan senang; (b) Untuk memotivasi siswa, guru memberikan apersepsi pembelajaran dengan mengingatkan kembali manfaat mempelajari sifat-sifat segitiga. (2) Kegiatan inti, (a) Guru menyampaikan inti materi pembelajaran yaitu sifat-sifat segitiga menurut besar sudut dan panjang sisinya; (b) Siswa diminta untuk berpikir (think) tentang sifat-sifat sifat-sifat segitiga menurut besar sudut dan panjang sisinya dengan membaca ringkasan materi tentang sifat-sifat segitiga menurut besar sudut dan panjang sisinya yang telah dibuat pada pertemuan ke-1; (c) Siswa diminta untuk berpasangan (pair) dengan teman sebelahnya (kelompok 2 orang) dan mengutarakan/berbagi (share) dengan tanya jawab berkaitan dengan hasil pemikiran masing-masing; (d) Guru memimpin pleno kecil diskusi, tiap-tiap kelompok mengemukakan hasil diskusinya; (e) Guru mengerahkan pembicaraan pada pokok permasalahan dan menambah materi yang belum diungkapkan para peserta didik; (f) Guru membagi kartu pertanyaan untuk mencatat pertanyaan-pertanyaan yang akan diajukan pada permainan KSD, dilanjutkan dengan pelaksanaan permainan KSD untuk permainan individu. (3) Penutup dengan kegiatan (a) Guru membantu siswa merangkum materi pelajaran; (b) Guru memberikan PR; (c) Guru memberi angket respon siswa; (e) Memberikan motivasi kepada siswa dengan memberitahukan materi yang akan dipelajari pada pertemuan selanjutnya yaitu sifat-sifat segiempat.

c. Pertemuan ke-3

Pertemuan ke-3 dilaksanakan pada hari Sabtu tanggal 16 Mei 2015 jam ke-1. Pada pertemuan ini guru memberikan soal Ulangan Siklus I untuk mengetahui prestasi belajar siswa. Guru juga memberikan angket refleksi pembelajaran kepada siswa.

3. Tahap Pengamatan Tindakan

a. Pertemuan ke-1 
1) Pengamat I mengamati jalannya kinerja guru dalam pengelolaan pembelajaran matematika. Dalam pengamatan ini digunakan lembar observasi yang telah dipersiapkan. Sedangkan Pengamat II mengamati keberanian siswa bertanya, hasil pengamatan dicatat pada lembar pengamatan.

2) Dari pengamatan guru diperoleh temuan sebagai berikut. (a) Penyampaian materi untuk apersepsi dalam pembelajaran sudah jelas dan sistematis karena guru telah mampu menguasai materi pelajaran; (b) Pengelolaan pembelajaran oleh guru belum terlaksana dengan baik karena guru dan siswa belum sepenuhnya memahami teknik pelaksanaannya; (c) Guru telah membimbing siswa atau kelompok yang masih mengalami kesulitan; (d) Guru masih terlalu dominan dalam kegiatan pembelajaran sehingga diskusi kelompok (berpasangan/pair) banyak diintervensi guru.

3) Dari pengamatan siswa diperoleh temuan sebagai berikut. (a) Suasana kelas kurang terkendali saat pembelajaran berlangsung. Siswa belum terbiasa dengan kerja kelompok (berpasangan/pair); (b) Keberanian siswa untuk menjawab pertanyaan dalam diskusi kelompok (berpasangan/pair) belum tumbuh. Siswa masih merasa takut salah; (c) Penampilan siswa dalam mempresentasikan hasil kerjanya dalam diskusi kelompok (berpasangan/pair) masih tampak ragu-ragu, tegang, dan kurang berani memandang teman-temannya akibatnya suara kurang keras

4) Hasil pengamatan aspek keberanian siswa bertanya dalam pembelajaran diperoleh data sebagai berikut. (a) siswa dengan kategori amat berani 3 siswa; (b) siswa dengan kategori berani 14 siswa; (c) siswa dengan kategori cukup berani 7 siswa; dan (d) siswa dengan kategori tidak berani 3 siswa. Masih ditemukan beberapa siswa dari kelompok yang hanya mencontoh kelompok lain. Ada 7 (tujuh) kelompok dari 14 (empat belas) kelompok diskusi berpasangan (pair) yang masih salah dalam menyampaikan gagasannya secara lesan karena kurang teliti.

b. Pertemuan ke-2

1) Pengamat I mengamati jalannya kinerja guru dalam pengelolaan pembelajaran matematika. Dalam pengamatan ini digunakan lembar observasi yang telah dipersiapkan. Sedangkan Pengamat II mengamati keberanian siswa bertanya, hasil pengamatan dicatat pada lembar pengamatan.

2) Dari pengamatan guru diperoleh temuan sebagai berikut. (a) Penyampaian materi untuk apersepsi dalam pembelajaran sudah jelas dan sistematis karena guru telah mampu menguasai materi pelajaran; (b) Pengelolaan pembelajaran oleh guru sudah terlaksana dengan baik karena guru dan siswa sudah sepenuhnya memahami teknik pelaksanaannya; (c) Guru telah membimbing siswa atau kelompok yang masih mengalami kesulitan; (d) Guru sudah tidak terlalu dominan dalam kegiatan pembelajaran sehingga diskusi kelompok (berpasangan/pair) tidak banyak diintervensi.

3) Dari pengamatan siswa diperoleh temuan sebagai berikut. (a) Suasana kelas sudah terkendali saat pembelajaran berlangsung. Siswa sudah terbiasa dengan kerja kelompok (berpasangan/pair); (b) Keberanian siswa untuk menjawab pertanyaan dalam diskusi kelompok (berpasangan/pair) sudah tumbuh dengan baik. Siswa sudah tidak merasa takut salah; (c) Penampilan siswa dalam mempresentasikan hasil kerjanya dalam diskusi kelompok (berpasangan/pair) sudah tidak ragu-ragu, tidak tegang, dan sudah berani memandang teman-temannya sehingga suara sangat jelas. 
4) Hasil pengamatan aspek keberanian siswa bertanya dalam pembelajaran diperoleh data sebagai berikut. (a) siswa dengan kategori amat berani 3 siswa; (b) siswa dengan kategori berani 14 siswa; (c) siswa dengan kategori cukup berani 7 siswa; dan (d) siswa dengan kategori tidak berani 3 siswa. Namun masih ditemukan beberapa siswa dari kelompok yang hanya mencontoh kelompok lain dan ada 5 (lima) kelompok dari 14 (empat belas) kelompok diskusi berpasangan (pair) yang masih salah dalam menyampaikan gagasannya secara lesan karena kurang teliti.

4. Tahap Refleksi Tindakan

a. Keberanian siswa bertanya kepada guru pada pembelajaran dengan RPP-1 pada pertemuan ke-1 dan ke-2 sudah meningkat walaupun peningkatannya belum memuaskan. Rekap keberanian siswa bertanya pada Siklus I seperti tercantum pada Tabel 5.

Tabel 5. Rekap Keberanian Siswa Bertanya pada Siklus I

\begin{tabular}{|c|c|c|c|c|}
\hline \multirow{2}{*}{ Keberanian siswa bertanya } & \multicolumn{2}{|c|}{ Pertemuan ke- } & \multirow{2}{*}{ Rata-rata } & \multirow{2}{*}{$\%$} \\
\hline & 1 & 2 & & \\
\hline Amat berani & 3 & 3 & 3 & $11 \%$ \\
\hline Berani & 14 & 14 & 14 & $52 \%$ \\
\hline Cukup berani & 7 & 7 & 7 & $26 \%$ \\
\hline Tidak berani & 3 & 3 & 3 & $11 \%$ \\
\hline
\end{tabular}

Berdasarkan Tabel 5 maka dapat disimpulkan keberanian siswa bertanya kepada pada Siklus I baru mencapai 63\%. Walaupun keberanian bertanya siswa belum memenuhi target penelitian namun dibandingkan dengan kondisi awal (pra-Siklus) sudah ada peningkatan. Dari hasil wawancara dengan siswa khususnya untuk siswa yang berada pada kategori cukup dan tidak berani mengajukan pertanyaan kepada guru diperoleh kesimpulan bahwa (1) setelah kegiatan belajar mengajar menggunakan pembelajaran Think-Pare-Share membuat mereka tidak lebih mudah memahami materi pelajaran; (2) mereka tidak senang dengan model pembelajaran yang digunakan guru; (3) mereka tidak berani untuk bertanya/menjawab pertanyaan guru karena mereka malu dikira tidak paham dan tidak pandai; (4) mereka masih mengalami kesulitan untuk mengungkapkan ide atau gagasan dalam diskusi kelompok/berpasangan (pair) karena diliputi rasa malu.

b. Dari hasil tes prestasi belajar Siklus I, nilai tertinggi prestasi belajar siswa 95, nilai terendah 50 , dengan rata-rata nilai 72 , dan ketuntasan klasikal $67 \%$ atau hanya 18 siswa yang mampu mencapai nilai di atas KKM 75. Sehingga masih ada 9 siswa atau $33 \%$ yang nilai prestasi belajarnya masih di bawah KKM.

c. Secara garis besar pelaksanaan siklus I belum sesuai dengan target penelitian sehingga masih diperlukan perbaikan-perbaikan.

\section{Deskripsi Siklus II}

1. Tahap Perencanaan Tindakan. (a) Menyusun 1 (satu) RPP untuk 2 (dua) pertemuan dengan materi sifat-sifat segiempat. Pertemuan ke-1 permainan KSD untuk permainan kelompok dan pertemuan ke-2 untuk permainan individu; (b) Menyiapkan bahan bacaan yang memuat sifatsifat segiempat; (c) Menyiapkan lembar kerja siswa untuk membuat Ringkasan Materi tentang Sifat-Sifat Segiempat; (d) Menyiapkan soal-soal untuk ulangan akhir Siklus II; (e) Mempersiapkan lembar pengamatan untuk mengamati situasi dan kondisi kegiatan 
pembelajaran, yaitu lembar pengamatan untuk keberanian siswa bertanya; ( $f$ ) Mempersiapkan angket respon siswa dan angket refleksi siswa dalam pembelajaran.

2. Tahap Pelaksanaan Tindakan

a. Pertemuan ke-1

Pertemuan ke-1 dilaksanakan pada hari Senin tanggal 18 Mei 2014 jam ke-2 dan ke-3 berisi penyampaian materi tentang sifat-sifat segiempat. Kemudian dilanjutkan dengan pemberian tugas, pembahasan dan penarikan kesimpulan secara bersama-sama. Semuanya dilaksanakan melalui Pembelajaran TPS berbantuan media permainan KSD sebagai berikut. (1) Pendahuluan, (a) Guru membuka pelajaran, dilanjutkan dengan menyampaikan SK, KD, indikator dan tujuan pembelajaran, skenario pembelajaran yang akan digunakan, mendeskripsikan berbagai kebutuhan logistik penting, dan memotivasi siswa untuk terlibat dalam kegiatan pembelajaran dengan aktif dan senang; (b) Untuk memotivasi siswa, guru memberikan apersepsi pembelajaran dengan mengingatkan siswa tentang manfaat mempelajari sifat-sifat segiempat. (2) Kegiatan inti, (a) Guru menyampaikan inti materi pembelajaran yaitu sifat-sifat segiempat; (b) Siswa diminta untuk berpikir (think) tentang sifat-sifat sifat-sifat segiempat dilanjutkan membuat ringkasan materi tentang sifat-sifat segiempat; (c) Siswa diminta untuk berpasangan (pair) dengan teman sebelahnya (kelompok 2 orang) dan mengutarakan/berbagi (share) dengan tanya jawab berkaitan dengan hasil pemikiran masing-masing; (d) Guru memimpin pleno kecil diskusi, tiap-tiap kelompok mengemukakan hasil diskusinya; (e) Guru mengerahkan pembicaraan pada pokok permasalahan dan menambah materi yang belum diungkapkan para peserta didik; (f) Guru membagi kartu pertanyaan untuk mencatat pertanyaan-pertanyaan yang akan diajukan pada permainan KSD, dilanjutkan dengan pelaksanakan permainan KSD untuk permainan kelompok dengan masing-masing beranggotakan 4 siswa. (3) Penutup dengan kegiatan (a) Guru membantu siswa merangkum materi pelajaran; (b) Guru memberikan PR; (c) Guru memberi angket respon siswa; (d) Memberikan motivasi kepada siswa dengan memberitahukan materi yang akan dipelajari pada pertemuan selanjutnya.

b. Pertemuan ke-2

Pertemuan ke-2 dilaksanakan pada hari Jumat tanggal 22 Mei 2015 jam ke-1 dan ke-2 berisi penyampaian materi tentang sifat-sifat segiempat. Kemudian dilanjutkan dengan pemberian tugas, pembahasan dan penarikan kesimpulan secara bersama-sama. Semuanya dilaksanakan melalui Pembelajaran TPS berbantuan media permainan KSD sebagai berikut. (1) Pendahuluan, (a) Guru membuka pelajaran, dilanjutkan dengan menyampaikan SK, KD, indikator dan tujuan pembelajaran, skenario pembelajaran yang akan digunakan, mendeskripsikan berbagai kebutuhan logistik penting, dan memotivasi siswa untuk terlibat dalam kegiatan pembelajaran dengan aktif dan senang; (b) Untuk memotivasi siswa, guru memberikan apersepsi pembelajaran dengan mengingatkan kembali manfaat mempelajari sifat-sifat segiempat. (2) Kegiatan inti, (a) Guru menyampaikan inti materi pembelajaran yaitu sifat-sifat segiempat; (b) Siswa diminta untuk berpikir (think) tentang sifat-sifat sifat-sifat segiempat dengan membaca ringkasan materi tentang sifat-sifat segiempat yang telah dibuat pada pertemuan ke-1; (c) Siswa diminta untuk berpasangan (pair) dengan teman sebelahnya (kelompok 2 orang) dan mengutarakan/berbagi (share) dengan tanya jawab berkaitan dengan hasil pemikiran masing-masing; (d) Guru memimpin pleno kecil diskusi, tiap-tiap kelompok mengemukakan hasil diskusinya; (e) Guru mengerahkan pembicaraan pada pokok permasalahan dan 
menambah materi yang belum diungkapkan para peserta didik; (f) Guru membagi kartu pertanyaan untuk mencatat pertanyaan-pertanyaan yang akan diajukan pada permainan $\mathrm{KSD}$, dilanjutkan dengan pelaksanaan permainan KSD untuk permainan individu. (3) Penutup dengan kegiatan (a) Guru membantu siswa merangkum materi pelajaran; (b) Guru memberikan PR; (c) Guru memberi angket respon siswa.

c. Pertemuan ke-3

Pertemuan ke-3 dilaksanakan pada hari Sabtu tanggal 23 Mei 2015 jam ke-1. Pada pertemuan ini guru memberikan soal Ulangan Siklus II untuk mengetahui prestasi belajar siswa. Guru juga memberikan angket refleksi pembelajaran kepada siswa.

3. Tahap Pengamatan Tindakan

a. Pertemuan ke-1

1) Pengamat I mengamati jalannya kinerja guru dalam pengelolaan pembelajaran matematika. Dalam pengamatan ini digunakan lembar observasi yang telah dipersiapkan. Sedangkan Pengamat II mengamati keberanian siswa bertanya, hasil pengamatan dicatat pada lembar pengamatan.

2) Dari pengamatan guru diperoleh temuan sebagai berikut. (a) Penyampaian materi untuk apersepsi dalam pembelajaran sudah sangat jelas dan sistematis karena guru telah mampu menguasai materi pelajaran; (b) Pengelolaan pembelajaran oleh guru sudah terlaksana dengan sangat baik karena guru dan siswa sudah sepenuhnya memahami teknik pelaksanaannya; (c) Guru telah membimbing siswa atau kelompok yang masih mengalami kesulitan; (d) Guru sudah tidak mendominasi dalam kegiatan pembelajaran sehingga diskusi kelompok (berpasangan/pair) tanpa diintervensi guru.

3) Dari pengamatan siswa diperoleh temuan sebagai berikut. (a) Suasana kelas sangat terkendali saat pembelajaran berlangsung. Siswa sudah sangat terbiasa dengan kerja kelompok (berpasangan/pair); (b) Keberanian siswa untuk menjawab pertanyaan dalam diskusi kelompok (berpasangan/pair) sudah sangat tumbuh. Siswa sudah tidak merasa takut salah; (c) Penampilan siswa dalam mempresentasikan hasil kerjanya dalam diskusi kelompok (berpasangan/pair) sudah tidak tampak ragu-ragu, tidak tegang, dan berani memandang teman-temannya sehingga suara sangat jelas.

4) Hasil pengamatan aspek keberanian siswa bertanya dalam pembelajaran diperoleh data sebagai berikut. (a) siswa dengan kategori amat berani 5 siswa; (b) siswa dengan kategori berani 16 siswa; (c) siswa dengan kategori cukup berani 4 siswa; dan (d) siswa dengan kategori tidak berani 2 siswa. Tidak ditemukan lagi siswa dari kelompok yang hanya mencontoh kelompok lain. Namun masih ada 4 (empat) kelompok dari 14 (empat belas) kelompok diskusi berpasangan (pair) yang masih salah dalam menyampaikan gagasannya secara lesan karena kurang teliti.

b. Pertemuan ke-2

1) Pengamat I mengamati jalannya kinerja guru dalam pengelolaan pembelajaran matematika. Dalam pengamatan ini digunakan lembar observasi yang telah dipersiapkan. Sedangkan Pengamat II mengamati keberanian siswa bertanya, hasil pengamatan dicatat pada lembar pengamatan.

2) Dari pengamatan guru diperoleh temuan sebagai berikut. (a) Penyampaian materi untuk apersepsi dalam pembelajaran sudah sangat jelas dan sistematis karena guru telah mampu menguasai materi pelajaran; (b) Pengelolaan pembelajaran oleh guru sudah terlaksana dengan baik karena guru dan siswa sudah sepenuhnya sangat memahami 
teknik pelaksanaannya; (c) Guru telah membimbing siswa atau kelompok yang masih mengalami kesulitan; (d) Guru sudah tidak mendominasi dalam kegiatan pembelajaran sehingga diskusi kelompok (berpasangan/pair) tidak lagi diintervensi oleh guru.

3) Dari pengamatan siswa diperoleh temuan sebagai berikut. (a) Suasana kelas sudah sangat terkendali saat pembelajaran berlangsung. Siswa sudah terbiasa dengan kerja kelompok (berpasangan/pair); (b) Keberanian siswa untuk menjawab pertanyaan dalam diskusi kelompok (berpasangan/pair) sudah tumbuh dengan sangat baik. Siswa sudah tidak merasa takut salah; (c) Penampilan siswa dalam mempresentasikan hasil kerjanya dalam diskusi kelompok (berpasangan/pair) sudah tidak tampak ragu-ragu, tidak tegang, dan sudah berani memandang teman-temannya sehingga suara sangat jelas.

4) Hasil pengamatan aspek keberanian siswa bertanya dalam pembelajaran diperoleh data sebagai berikut. (a) siswa dengan kategori amat berani 5 siswa; (b) siswa dengan kategori berani 16 siswa; (c) siswa dengan kategori cukup berani 4 siswa; dan (d) siswa dengan kategori tidak berani 2 siswa. Sudah tidak ditemukan lagi siswa dari suatu kelompok yang hanya mencontoh kelompok lain, namun masih ada 2 (dua) kelompok dari 14 (empat belas) kelompok diskusi berpasangan (pair) yang masih salah dalam menyampaikan gagasannya secara lesan karena kurang teliti.

4. Tahap Refleksi Tindakan

a. Keberanian siswa bertanya kepada guru pada pembelajaran pada pertemuan ke-1 dan ke-2 sudah meningkat dengan peningkatan sangat memuaskan. Rekap keberanian siswa bertanya pada Siklus II seperti tercantum pada Tabel 6 berikut.

Tabel 6. Rekap Keberanian Siswa Bertanya pada Siklus II

\begin{tabular}{|c|c|c|c|c|}
\hline \multirow[b]{2}{*}{ Keberanian siswa bertanya } & \multicolumn{2}{|c|}{ Pertemuan ke- } & \multirow[b]{2}{*}{ Rata-rata } & \multirow[b]{2}{*}{$\%$} \\
\hline & 1 & 2 & & \\
\hline Amat berani & 5 & 5 & 5 & $19 \%$ \\
\hline Berani & 16 & 16 & 16 & $59 \%$ \\
\hline Cukup berani & 4 & 4 & 4 & $15 \%$ \\
\hline Tidak berani & 2 & 2 & 2 & $7 \%$ \\
\hline
\end{tabular}

Berdasarkan Tabel 6 di atas maka dapat disimpulkan keberanian siswa bertanya kepada pada Siklus II mencapai 78\%. Walaupun keberanian siswa bertanya sudah memenuhi target penelitian namun namun dari hasil wawancara dengan siswa khususnya untuk siswa yang berada pada kategori cukup berani mengajukan pertanyaan kepada guru diperoleh kesimpulan bahwa (1) setelah kegiatan belajar mengajar menggunakan pembelajaran Think-Pare-Share membuat mereka tidak lebih mudah memahami materi pelajaran; (2) mereka tidak senang dengan model pembelajaran yang digunakan guru; (3) mereka cukup berani untuk bertanya/menjawab pertanyaan guru namun mereka masih merasa malu karena dikira tidak paham dan tidak pandai; (4) mereka masih mengalami kesulitan untuk mengungkapkan ide atau gagasan dalam diskusi kelompok/berpasangan (pair) karena diliputi rasa malu.

b. Dari hasil tes prestasi belajar Siklus II, nilai tertinggi prestasi belajar siswa 100 , nilai terendah 65 , dengan rata-rata nilai 82 , dan ketuntasan klasikal $78 \%$ atau 21 siswa yang telah mampu mencapai nilai di atas KKM 75. Namun masih ada 6 siswa atau 22\% yang nilai 
prestasi belajarnya masih di bawah KKM. Secara garis besar pelaksanaan siklus II sudah sesuai dengan target penelitian.

\section{Pembahasan Tiap Siklus dan Antarsiklus}

\section{Siklus I}

Pada dasarnya, tindakan pada Siklus I telah menghasilkan perbaikan dan peningkatan dalam keberanian siswa bertanya maupun prestasi belajar siswa (nilai tertinggi rata-tata, nilai terendah, rata-rata nilai, dan ketuntasan belajar).

Peningkatan keberanian siswa bertanya maupun prestasi belajar siswa dengan pembelajaran Think Pair Share (TPS) berbantuan media permainan Kuis Siapa Dia (KSD) dapat dilihat dari peningkatan pada Siklus I dibandingkan dengan pra-Siklus (Kondisi Awal), seperti tercantum pada paparan Tabel 6.

Tabel 7. Keberanian Siswa Bertanya pada Pra-Siklus dan Siklus I

\begin{tabular}{lrrrrrr}
\hline \multicolumn{1}{c}{ Keberanian siswa bertanya } & \multicolumn{2}{c}{ Pra Siklus } & \multicolumn{2}{c}{ Siklus I } & \multicolumn{2}{c}{ Peningkatan } \\
\hline Amat berani & 2 & $7 \%$ & 3 & $11 \%$ & 1 & $4 \%$ \\
Berani & 10 & $37 \%$ & 14 & $52 \%$ & 4 & $15 \%$ \\
Cukup berani & 9 & $33 \%$ & 7 & $26 \%$ & -2 & $-7 \%$ \\
Tidak berani & 6 & $22 \%$ & 3 & $11 \%$ & -3 & $-11 \%$ \\
\hline
\end{tabular}

Berdasarkan Tabel 7, keberanian siswa bertanya baru mencapai $73 \%$ atau 17 siswa yang keberanian bertanya dalam kategori minimal berani, hal ini masih di bawah dari target penelitian sebesar 75\%, namun begitu dibandingkan dengan kondisi awal (pra-Siklus) sudah terjadi peningkatan sebesar 19\%. Ketidaktercapaian indikator kinerja pada Siklus I disebabkan oleh (1) siswa masih canggung dan binggung dengan pembelajaran Think Pair Share dengan berbantuan media permainan Kuis Siapa Dia? (KSD); (2) Guru belum maksimal memberikan bimbingan kepada siswa yang masih pasif saat pembelajaran tahap berpikir (think) mandiri maupun diskusi kelompok (berpasangan/pair); (3) Hampir 36\% dari kelompok diskusi kelompok (berpasangan/pair), masih binggung saat melakukan diskusi kelompok (berpasangan/pair) dalam menyelesaikan soal-soal matematika yang diberikan guru. Walaupun belum mencapai indikator penelitian, namun hasil tindakan Siklus I telah dapat meningkatkan rata-rata prestasi belajar siswa dan ketuntasan belajar secara klasikal dibandingkan kondisi sebelum tindakan (pra-Siklus). Peningkatan rata-rata prestasi belajar siswa pada Siklus I didukung oleh peningkatan keberanian siswa bertanya kepada guru apabila menemui hal-hal yang menurut mereka belum paham atau dirasakan sulit. Dengan tanya jawab guru membimbing siswa untuk memecahkan masalah yang dihadapinya. Pencapaian prestasi belajar pada Siklus I selengkapnya pada Tebel 8.

Tabel 8. Prestasi belajar siswa pada pra-Siklus dan Siklus I

\begin{tabular}{|c|c|c|c|}
\hline Uraian Prestasi Belajar & Pra Siklus & Siklus I & Peningkatan \\
\hline Nilai tertinggi & 85 & 95 & 10 \\
\hline Nilai terendah & 40 & 50 & 10 \\
\hline Rata-rata & 59 & 72 & 13 \\
\hline Tuntas & $37 \%$ & $67 \%$ & $30 \%$ \\
\hline Tidak tuntas & $63 \%$ & $33 \%$ & $-30 \%$ \\
\hline
\end{tabular}


Berdasarkan Tabel 8 disimpulkan bahwa Siklus I belum mencapai target penelitian pada aspek prestasi belajar sehingga tindakan perlu dilanjutkan pada Siklus II.

\section{Siklus II}

Pada dasarnya, tindakan pada Siklus II telah menghasilkan perbaikan dan peningkatan dalam keberanian siswa bertanya maupun prestasi belajar siswa (nilai tertinggi rata-tata, nilai terendah, rata-rata nilai, dan ketuntasan belajar) dibandingkan dengan Siklus I. Peningkatan keberanian siswa bertanya maupun prestasi belajar siswa dengan pembelajaran Think Pair Share (TPS) berbantuan media permainan Kuis Siapa Dia? (KSD) dapat dilihat dari peningkatan pada Siklus II dibandingkan dengan Siklus I, seperti tercantum pada paparan Tabel 9.

Tabel 9. Keberanian Siswa Bertanya pada Siklus I dan Siklus II

\begin{tabular}{lrrrrrr}
\hline \multicolumn{1}{c}{ Keberanian siswa bertanya } & \multicolumn{2}{c}{ Siklus I } & \multicolumn{2}{c}{ Siklus II } & \multicolumn{2}{c}{ Peningkatan } \\
\hline Amat berani & 3 & $11 \%$ & 5 & $19 \%$ & 2 & $8 \%$ \\
Berani & 14 & $52 \%$ & 16 & $59 \%$ & 2 & $7 \%$ \\
Cukup berani & 7 & $26 \%$ & 4 & $15 \%$ & -3 & $-12 \%$ \\
Tidak berani & 3 & $11 \%$ & 2 & $7 \%$ & -1 & $-4 \%$ \\
\hline
\end{tabular}

Berdasarkan Tabel 9, keberanian siswa bertanya telah mencapai 78\% atau 21 siswa yang keberanian bertanya dalam kategori minimal berani, hal ini melebihi dari target penelitian sebesar $75 \%$, sehingga dibandingkan dengan Siklus I sudah terjadi peningkatan sebesar $5 \%$. Ketercapaian indikator kinerja pada Siklus II disebabkan oleh (1) siswa sudah tidak canggung dan dan tidak binggung lagi dengan pembelajaran Think Pair Share dengan berbantuan media permainan Kuis Siapa Dia? (KSD) bahkan komentar sebagian besar sangat menyukai pembelajaran ini; (2) Guru sudah maksimal memberikan bimbingan kepada siswa yang masih pasif saat pembelajaran tahap berpikir (think) mandiri maupun diskusi kelompok (berpasangan/pair); (3) Namun masih ada 7\% dari kelompok diskusi kelompok (berpasangan/pair), masih binggung saat melakukan diskusi kelompok (berpasangan/pair) dalam menyelesaikan soal-soal matematika yang diberikan guru. Tindakan Siklus II juga telah dapat meningkatkan rata-rata prestasi belajar siswa dan ketuntasan belajar secara klasikal.

Tabel 10. Prestasi belajar siswa pada Siklus I dan Siklus II

\begin{tabular}{|c|c|c|c|}
\hline Uraian Prestasi Belajar & Siklus I & Siklus II & Peningkatan \\
\hline Nilai tertinggi & 95 & 100 & 5 \\
\hline Nilai terendah & 50 & 65 & 5 \\
\hline Rata-rata & 72 & 82 & 10 \\
\hline Tuntas & $67 \%$ & $78 \%$ & $11 \%$ \\
\hline Tidak tuntas & $33 \%$ & $22 \%$ & $-11 \%$ \\
\hline
\end{tabular}

Peningkatan rata-rata prestasi belajar siswa pada Siklus II didukung oleh peningkatan keberanian siswa bertanya kepada guru apabila menemui hal-hal yang menurut mereka belum paham atau dirasakan sulit. Dengan tanya jawab guru membimbing siswa untuk memecahkan masalah yang dihadapinya. Pencapaian prestasi belajar pada Siklus II selengkapnya pada Tabel 10. 
Berdasarkan Tabel 10 disimpulkan bahwa Siklus II sudah mencapai target penelitian pada aspek prestasi belajar sehingga tindakan tidak perlu dilanjutkan pada Siklus III.

\section{HASIL PENELITIAN}

Setelah dilaksanakan tindakan dan perbaikan didapatkan hasil yang positif dan signifikan, baik secara kuantitatif maupun kualitatif. Hasil tersebut dapat dilihat dari keberanian siswa bertanya kepada guru apabila menjumapai hal-hal yang belum mereka pahami atau dirasa sulit demikian juga prestasi belajar siswa yang meningkat. Hasil lengkap peningkatan keberanian siswa bertanya pada Tabel 11.

Tabel 11. Rangkuman Keberanian Siswa Bertanya Pada Pra-Siklus, Siklus I, dan Siklus II

\begin{tabular}{lrrrrrrr}
\hline \multicolumn{1}{c}{ Keberanian siswa bertanya } & \multicolumn{2}{c}{ pra-Siklus } & \multicolumn{2}{c}{ Siklus I } & \multicolumn{2}{c}{ Siklus II } & Keterangan \\
\hline Amat berani & 2 & $7 \%$ & 3 & $11 \%$ & 5 & $19 \%$ & Meningkat \\
Berani & 10 & $37 \%$ & 14 & $52 \%$ & 16 & $59 \%$ & Meningkat \\
Cukup berani & 9 & $33 \%$ & 7 & $26 \%$ & 4 & $15 \%$ & Meningkat \\
Tidak berani & 6 & $22 \%$ & 3 & $11 \%$ & 2 & $7 \%$ & Meningkat \\
\hline
\end{tabular}

Berdasarkan Tabel 11 dapat disimpulkan bahwa tindakan 2 (dua) siklus telah mampu meningkatkan keberanian siswa bertanya. Keberanian siswa bertanya meningkat, hal ini dapat dilihat (a) siswa dengan kategori amat berani meningkat dari 2 siswa (pra-Siklus) menjadi 3 siswa (Siklus I) dan 5 siswa (Siklus II); (b) siswa dengan kategori berani meningkat dari 10 siswa (pra-Siklus) menjadi 14 siswa (Siklus I) dan 16 siswa (Siklus II); (c) siswa dengan kategori cukup menurun (meningkat negatif) dari 9 siswa (pra-Siklus) menjadi 7 siswa (Siklus I) dan 4 siswa (Siklus II); dan (d) siswa dengan kategori tidak berani menueun (meningkat negatif) dari 6 siswa (pra-Siklus) menjadi 3 siswa (Siklus I) dan 2 siswa (Siklus II). Peningkatan keberanian siswa bertanya dari kondisi awal (pra-Siklus), Siklus I, dan Siklus II lebih jelasnya dapat disimak pada Grafik 1.

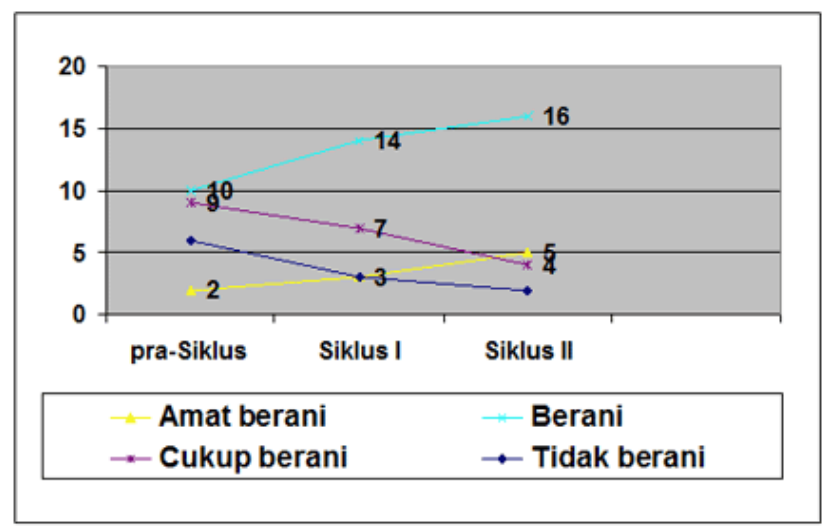

Grafik 1. Keberanian siswa bertanya kondisi awal (pra Siklus), Siklus I, Siklus II

Peningkatan dari pra-Siklus, Siklus I dan Siklus II juga ditunjukkan oleh peningkatan prestasi belajar siswa hal ini dapat dilihat dari nilai tertinggi, nilai terendah, rata-rata nilai, dan ketuntasan belajar klasikal. Hasil lengkap peningkatan prestasi belajar siswa pada Tabel 12. 
Tabel 12. Rangkuman Keberanian Siswa Bertanya Pada Pra-Siklus, Siklus I, dan Siklus II

\begin{tabular}{|c|c|c|c|c|c|c|c|}
\hline \multirow{4}{*}{\begin{tabular}{l}
\multicolumn{1}{c}{ Uraian Prestasi Belajar } \\
Nilai tertinggi \\
Nilai terendah \\
Rata-rata
\end{tabular}} & \multicolumn{2}{|c|}{ Pra-Siklus } & \multicolumn{2}{|c|}{ Siklus I } & \multicolumn{2}{|c|}{ Siklus II } & Keterangan \\
\hline & \multicolumn{2}{|c|}{85} & \multicolumn{2}{|c|}{95} & \multicolumn{2}{|c|}{100} & Meningkat \\
\hline & & 40 & & 50 & & 65 & Meningkat \\
\hline & & 59 & & 72 & & 82 & Meningkat \\
\hline Tuntas & 10 & $37 \%$ & 18 & $67 \%$ & 21 & $78 \%$ & Meningkat \\
\hline Tidak tuntas & 17 & $63 \%$ & 9 & $33 \%$ & 6 & $22 \%$ & Meningkat \\
\hline
\end{tabular}

Berdasarkan Tabel dapat simpulkan bahwa tindakan 2 (dua) siklus telah mempu meningkatkan prestasi belajar siswa. Nilai tertinggi pada kondisi awal (pra-Siklus) 85 meningkat menjadi 95 pada Siklus I dan 100 pada Siklus II. Nilai terendah pada kondisi awal (pra-Siklus) 40 meningkat menjadi 50 pada Siklus I dan 65 pada Siklus II. Rata-rata nilai pada kondisi awal (praSiklus) 59 meningkat menjadi 72 pada Siklus I dan 82 pada Siklus II. Ketuntasan belajar klasikal pada kondisi awal (pra-Siklus) $37 \%$ meningkat menjadi $67 \%$ pada Siklus I dan $78 \%$ pada Siklus II. Peningkatan prestasi belajar siswa dari kondisi awal (pra-Siklus), Siklus I, dan Siklus II lebih jelasnya dapat disimak pada Grafik 2.

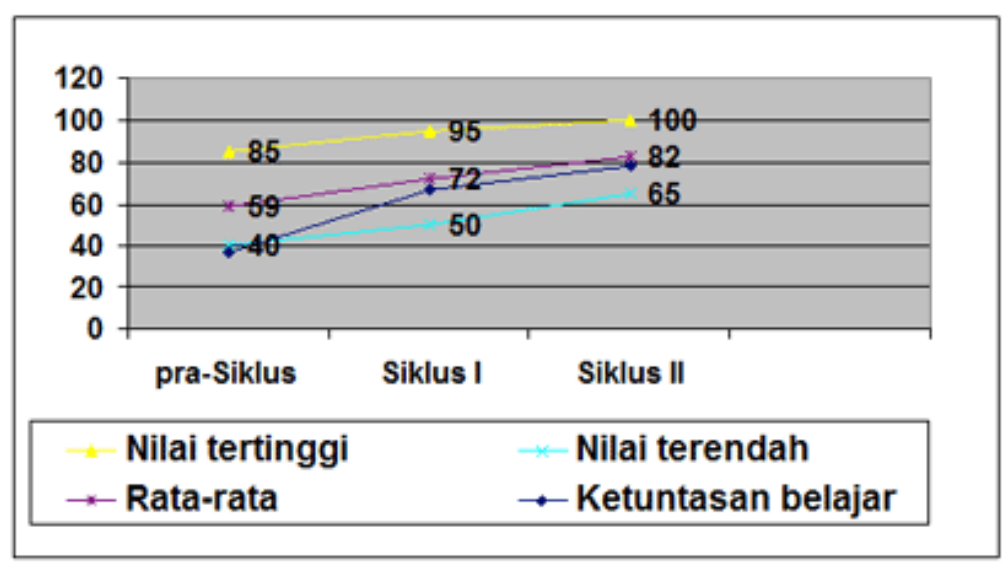

Grafik.2. Peningkatan prestasi belajar siswa Pra-Siklus, Siklus I, Siklus II

Hasil penelitian ini memperkuat pendapat bahwa pembelajaran Think Pair Share dikembangkan oleh Frank Lyman atau Think Pair Square dikembangkan oleh Spencer Kagan sebagai struktur kegiatan pembelajaran Cooperative Learning (Lie, 2010, hal. 57). Pembelajaran Think Pair Share (TPS) merupakan bagian dari model pembelajaran kooperatif yang berprinsip PAIKEM (Pembelajaran yang Aktif, Inovatif, Kreatif, dan Menyenangkan). Penelitian ini juga memperkuat hasil penelitian yang dilakukan oleh Marion Reba'i (2006) dengan menggunakan kartu pertanyaan. Siswa mengajukan pertanyaan ditulis pada kartu pertanyaan kemudian kartu diberikan kepada guru. Kartu pertanyaan digunakan dalam penelitian ini untuk mencatat pertanyaanpertanyaan yang akan diajukan kepada moderator permainan Kuis Siapa Dia (KSD). Juga memperkuat hasil penelitian Amin Subhan, Siska Desy Fatmaryanti, dan Nur Hidayati (2013) menggunakan model pembelajaran aktif tipe Card Sort yang akan menggugah semangat dan antusias siswa dalam bertanya melalui kerja kelompok memilah kartu, menemukan pasangan, berdiskusi mengemukakan pendapat dan membuat pertanyaan untuk kelompok lain. 
Permainan Kuis Siapa Dia (KSD) yang dirancang dengan tepat untuk pembelajaran sehingga bermanfaat bagi siswa yang mengalami masalah belajar dalam mengajukan pertanyaan kepada guru serta untuk membantu siswa-siswa yang memperlihatkan masalah disiplin yang disebabkan kebosanan dengan rutinitas ruang kelas, hal ini sesuai dengan pendapat Wahyudin (2008: 40) bahwa penggunaan strategi permainan sewaktu-waktu di ruang kelas antara lain (1) Jika dirancang dengan tepat, permainan dapat bermanfaat bagi siswa-siswa yang mengalami masalah belajar tertentu misalnya kelemahan dalam berbahasa (keterampilan-keterampilan membaca atau verbal); (2) Permainan dapat digunakan untuk membantu siswa-siswa yang memperlihatkan masalah disiplin yang disebabkan kebosanan dengan rutinitas ruang kelas; (3) Permainan sangat sesuai di ruang kelas yang menggunakan pendekatan laboratorium atau pusat belajar. Hal ini mungkin ketika permainan diatur sedemikian hingga berjalan terlepas dari kendali guru secara langsung; (4) Permainan memberi kesempatan kepada para siswa untuk menerapkan kendali dan pengaruh terhadap lingkungan sosial mereka dengan memungkinkan pergeseran peran dari pengguna informasi yang pasif menjadi pembuat keputusan yang aktif; (5) Permainan dapat mengangkat interaksi-interaksi sosial yang menguntungkan di antara sesama siswa dengan mendorong terjadinya kerjasama dan diskusi; (6) Permainan dapat menyediakan informasi diagnostik bagi guru, yang dapat digunakannya untuk membantu para siswa memperbaiki miskonsepsi dan mengisi celah dalam struktur belajar mereka; (7) Permainan dapat digunakan untuk mengintegrasikan matematika dengan bidang-bidang studi lainnya dan dapat pula diarahkan sesuai dengan minat khusus siswa.

\section{SIMPULAN DAN SARAN}

Dari hasil penelitian tindakan kelas ini diperoleh beberapa simpulan yaitu (1) Pembelajaran kooperatif Think Pair Share berbantuan media permainan Kuis Siapa Dia (KSD) dapat meningkatkan keberanian siswa bertanya dan prestasi belajar materi segitiga dan segiempat bagi siswa kelas VII-A SMP Negeri 2 Patean Semester II Tahun Pelajaran 2014/2015; (2) Pembelajaran kooperatif Think Pair Share berbantuan media permainan Kuis Siapa Dia (KSD) dapat meningkatkan keberanian siswa bertanya materi segitiga dan segiempat bagi siswa kelas VII-A SMP Negeri 2 Patean Semester II Tahun Pelajaran 2014/2015 sebesar 34\%; (3) Pembelajaran kooperatif Think Pair Share berbantuan media permainan Kuis Siapa Dia? (KSD) materi segitiga dan segiempat dapat menuntaskan belajar siswa kelas VII-A SMP Negeri 2 Patean Semester II Tahun Pelajaran 2014/2015 sebesar 78\% artinya 21 siswa nilai prestasi belajarnya lebih dari KKM 75.

Berdasarkan simpulan hasil penelitian, maka peneliti merekomendasikan beberapa hal sebagai berikut. (1) Guru matematika yang mempunyai masalah dan karakteristik sama dapat memcoba menerapkan pembelajaran kooperatif Think Pair Share berbantuan media Kuis Siapa Dia (KSD) dengan penekanan untuk meningkatkan keberanian siswa bertanya dan prestasi belajar siswa, dengan mengantisipasi kelemahan-kelemahan yang mungkin terjadi; (2) Kepala sekolah dapat menganjurkan guru matematika untuk mencoba mengimplementasikan pembelajaran kooperatif Think Pair Share berbantuan media Kuis Siapa Dia (KSD) pada materi yang lain misalnya bangun ruang sisi datar (kelas VIII) atau bangun ruang sisi lengkung (kelas IX); (3) Dinas Pendidikan Kabupaten Kendal, dapat mengambil kebijakan yang selaras dengan penelitian ini, misalnya mengadakan workshop bagi guru Matematika lewat MGMP Matematika SMP Kabupaten Kendal untuk mensosialisasikan pembelajaran kooperatif Think Pair Share berbantuan media Kuis Siapa Dia (KSD).

Berdasarkan simpulan dan rekomendasi di atas, peneliti memberikan saran antara lain (1) Meskipun penelitian tindakan kelas ini hanya sampai 2 (dua) siklus dan sudah mencapai hipotesis 
tindakan, namun guru hendaknya terus mengadakan penelitian lanjutan agar kemampuan siswa meningkat; (2) Guru matematika dapat mengembangkan permainan Kuis Siapa Dia? (KSD) pada materi bangun ruang sisi datar (kelas VIII) atau bangun ruang sisi lengkung (kelas IX) dengan memodifikasinya.

\section{REFERENSI}

Amin Subhan, Siska Desy Fatmaryanti, Nur Hidayati. (2013). Keaktifan bertanya siswa dengan menggunakan model pembelajaran aktif tipe Card Sort pada kelas $\mathrm{X}$ madrasah aliyah wathoniyah islamiyah karangduwur. Jurnal radiasi, vol. 2(1), Pendidikan Fisika Universitas Muhammadiyah Purworejo.

Depdiknas. (2006). Peraturan menteri pendidikan nasional republik indonesia no. 22 tahun 2006 tentang stándar isi untuk satuan pendidikan dasar dan menengah. Jakarta: Direktorat Jenderal Pendidikan Dasar dan Menengah, Direktorat Pendidikan Lanjutan Pertama.

http://id.wikipedia.org/wiki/Siapa_Dia\%3F \%28kuis\%29. Diakses tanggal 19/04/2015 jam 06.10. Kementerian Pendidikan Nasional. (2010). Model-model pembelajaran. Disajikan pada TOT Guru pemandu MGMP SMP in service 1 Tahun II di LPMP Jawa Tengah. Semarang: Direktur Jenderal Peningkatan Mutu Pendidik dan Tenaga Kependidikan LPMP Jawa Tengah.

Lie, Anita. (2010). Cooperative learning mempraktikkan cooperative learning di ruang-ruang kelas. Jakarta: P.T. Grasindo.

Marion Reba'i. (2006). Peningkatan keberanian bertanya siswa menggunakan kartu pertanyaan kelas VIII.5 SMP Negeri 1 Tanjung Raja tahun pembelajaran 2005/2006. Laporan penelitian tidak kelas. Tidak diterbitkan.

Mulyono dkk. (1995). Kamus besar bahas Indonesia. Jakarta: PT Balai Pustaka.

Mustakim. (2015). Laporan pembuatan alat pelajaran "Permainan KSD". Tidak diterbitkan disimpan di perpustakaan sekolah.

Purwanti, Eko. (2003). Karakteristik dan pemilihan media pembelajaran. Materi workshop peningkatan pengelolaan sumber belajat guru SLTP/MTs. Semarang: Dinas Pendidikan Propinsi Jawa Tengah.

Rochmad. (2008). Penggunaan pola pikir induktif-deduktif dalam pembelajaran matematika beracuan konstruktivisme. Diakses pada tanggal 21 Maret 2008 dari http://www.rochmadunnes.blogspot.com,.

Suprijono, Agus. (2010). Cooperatif learning teori dan aplikasi PAIKEM. Yogyakarta: Pustaka pelajar. Wahyudin. (2008). Pembelajaran dan model-model pembelajaran (Pelengkap untuk meningkatkan kompetensi pedagogis para guru dan calon-calon profesional) Seri 3. Bandung: CV Ipa Abong. 